\title{
DOTAZNÍK STRATEGIÍ ZVLÁDÁNí STRESU (SVF-78) Recenze metody
}

\author{
AUTOŘI RECENZE: GABRIELA BINDEROVÁ ${ }^{1}$
}

\begin{tabular}{|l|l|}
\hline Datum vzniku recenze & 5.1 .2021 \\
\hline Název nástroje & Strategie zvládání stresu \\
\hline Zkrácený název & SVF-78 \\
\hline Původní název & Stressverarbeitungsfragebogens \\
\hline Autoři původního testu & W. Jankfe, G. Erdmann \\
\hline Autoři lokální adaptace & J. Švancara \\
\hline Lokální distributor & Hogrefe - Testcentrum \\
\hline Datum vydání & 2003 \\
\hline
\end{tabular}

\section{Obecný popis}

Dotazník Strategií zvládání stresu - SVF 78 je vícedimenzionální sebeposuzovací inventár̆ zachycující individuální tendence pro nasazení různých způsobů reagování na stres v zátěžových situacích. Jedná se o metodu typu papír-tužka, v českém prostředí existuje i počítačová verze, ta však není předmětem této recenze.

Test je určen pro dospělou populaci (normy pro rozmezí 20-64 let), autoři jej doporučují pro srovnávání skupin vystavených různým formám zátěže v různých oblastech, jako je psychologie zdraví a nemoci a pracovní psychologie. Interpretace výsledků v rámci individuální psychologické diagnostiky je dle autorů předmětem dalšího zkoumání validity. $V$ př́padě individuální diagnostiky autoři upozorňují na chybovost měření a možnou významnou odchylku získaného skóru od pravého, dále pak na problematiku aplikace výsledků na konkrétní zátěžové situace a možnou neochotu respondenta být sdílný.

Metoda obsahuje příručku, dotazník, vyhodnocovací list a testový profil. Součástí př́ručky jsou tabulky norem a převodů na T-skóry pro muže a ženy zvlášt'. Dotazník se skládá z 13 škál: Podhodnocení, Odmítání viny, Odklon, Náhradní uspokojení, Kontrola situace,

\footnotetext{
1 Katedra psychologie, Fakulta sociálních studií, Masarykova univerzita, Joštova 10, 60200 Brno
} 
Kontrola reakcí, Pozitivní sebeinstrukce, Potřeba sociální opory, Vyhýbání se, Úniková tendence, Perseverace, Rezignace, Sebeobviňování. Každá škála obsahuje 6 položek (celkem 78 položek), přičemž každá položka začíná stejným výrokem: „Když jsem něčím nebo někým poškozen/a, vnitřně rozrušen/a, nebo vyveden/a z míry...", načež je vždy věta doplněna určitým tvrzením, jehož subjektivní pravdivost hodnotí respondenti na pětibodové Likertově škále (vůbec ne - velmi pravděpodobně). Dotazník je administrován individuálně nebo ve skupině, vyplnění respondentům obvykle trvá 10-15 minut.

Vyhodnocování se provádí s pomocí vyhodnocovacího listu součtem skórů v rámci jednotlivých škál. Takto vzniklé hrubé skóry se dále převádí na T-skóry pomocí přiložených tabulek, které jsou převzaté z původní verze metody SVF 120. Průměrem součtu hrubých skórů určitých škál se dále získá hrubý skór celkových pozitivních (škály Podhodnocení, Odmítání viny, Odklon, Náhradní uspokojení, Kontrola situace, Kontrola reakce, Pozitivní sebedestrukce) a negativních strategií (škály Úniková tendence, Perseverace, Rezignace, Sebeobviňování), škály Potřeba sociální opory a Vyhýbání se nejsou řazeny ani do jednoho typu strategií a stojí samostatně, podle autorů mohou být pozitivní či negativní v závislosti na celkovém profilu v testu. Hrubé skóry pozitivních a negativních strategií lze opět pomocí tabulek převést na T-skóry. Pozitivní strategie je dále možné rozlišit na tři podtypy - Strategie podhodnocení a devalvace (škály Podhodnocení a Odmítání viny), Strategie odklonu (škály Odklon a Náhradní uspokojení) a Strategie kontroly (škály Kontrola situace, Kontrola reakce a Pozitivní sebeinstrukce), pro tyto podtypy však už nejsou poskytnuty převody na T-skóry.

\section{Vývoj}

SVF 78 vznikl zkrácením metody SVF 120 (původní verze z roku 1985, druhá upravená verze z roku 1997 (Weyers, Ising, Reuter a Janke, 2005), všech 13 škál SVF 78 bylo ve stejné podobě převzato z původní delší verze.

Při vývoji vycházeli autoři z několika předpokladů: Lidé na stres aktivně reagují snahou o obnovení klidového stavu, tyto způsoby zpracování stresu jsou přitom relativně stabilní v čase a lze je tak pojímat jako osobnostní rys. Lze rozlišit více na sobě relativně nezávislých způsobů zpracování stresu (multidimenzionalita), ty jsou dále relativně nezávislé na druhu zátěžové situace a nejsou rozhodujícím způsobem určovány jinými osobnostními charakteristikami. Způsoby zpracování stresu jsou natolik vědomé, že je možné se na ně přímo dotázat. Autoři přitom sami uvádějí, že některé tyto předpoklady nejsou dosud dostatečně objasněny, výzkumy jsou v některých případech rozporuplné (např. ohledně nezávislosti na situaci). Pokud by některé předpoklady neplatily, byla by ohrožena celková validita metody (v případě závislosti na situaci by např. nebylo možné usuzovat na jednání osoby v konkrétních kontextech a metoda by tím pádem ve své obecnosti neměla př́liš smysl).

Způsoby zpracování stresu lze dle autorů také rozdělit podle několika kritérií. Lze rozlišit akční způsoby směřující ke změně nebo odstranění stresoru/reakce na něj a 
intrapsychické způsoby směřující ke změně vnímání stresoru/reakce. Dále lze strategie rozdělit na zaměřené na stres (reakci při zátěži) a zaměřené na stresor (zátěžovou situaci). Nakonec pak podle účinnosti na pozitivní strategie, které stres spíše snižují, a negativní strategie, které stres v důsledku spíše zvyšují.

V manuálu není odkaz na žádnou existující teorii zvládání stresu, pouze v předmluvě pro české vydání Švancara zmiňuje teorii Lazaruse a zároveň dodává, že SVF je konceptualizované $\mathrm{v}$ jeho návaznosti. Autoři metody se však k teorii na žádném místě nehlásí, na rozdíl od Lazaruse navíc předpokládají poměrnou nezávislost strategií na situaci. Není zcela jasné, jakým způsobem byl vlastně test vytvořen a z čeho autoři vyvodili používané škály, ani na základě čeho je zařadili mezi pozitivní/negativní strategie. Nic $\mathrm{z}$ toho není v manuálu zmíněno, jediné informace o původu testu se týkají dílčích teoretických předpokladů uvedených výše a jeho odvození z původní verze SVF 120. Informace o konstrukci SVF 120 však nejsou volně dostupné. Balcar, Trnka a Kuška (2011) nicméně uvádí, že nevznikl na základě teorie, ale byl induktivně odvozen z popisu lidí, následné kategorizace a položkové analýzy.

Stejně tak nejsou součástí manuálu informace o vzniku českého překladu ani o psychometrických vlastnostech české verze.

\section{Technické parametry}

Předem je třeba říci, že veškeré psychometrické vlastnosti metody uváděné v manuálu pocházejí z jediné zahraniční standardizační studie (Weyers, Ising a Janke, 2005) a byly získány na německém vzorku 246 osob (122 žen a 124 mužů) ve věku 20-64 let. Níže uváděné výsledky jiných studií již nejsou součástí manuálu.

\section{Reliabilita}

V rámci standardizace metody (Weyers, Ising a Janke, 2005) byly na vzorku 246 osob, 122 žen a 124 mužů ve věku 20-64 let zjištěny hodnoty Cronbachovo $\alpha$ pro jednotlivé škály 0,77-0,94 a pro celkové pozitivní a negativní strategie a podtypy pozitivních strategií 0,86-94. Hodnoty split-half reliability se pak pro škály pohybovaly mezi $0,74-0,95$, pro pozitivní a negativní strategie $0,85-0,96$. Odhady reliability zde byly počítány pro muže a ženy zvlášt', vycházely ale velmi podobně, pouze u škál Náhradní uspokojení a Rezignace se objevily malé rozdíly. Reliabilita nicméně nebyla zkoumána zvlášt' pro jednotlivá věková období, což může souviset i s poměrně malou velikostí vzorku. V rámci předchozí verze dotazníku SVF 120 vycházela na vzorku 140 osob (69 mužů, 71 žen) Cronbachovo $\alpha$ a split-half reliabilita pro všechny škály a strategie vyšší než 0,7 , pro většinu pak více jak 0,8 a split-half reliabilita strategií vyšší než 0,9. Test-retest reliabilita po jednom měsíci pak vycházela pro všechny škály větší než 0,7 (Ising, Weyers, Reuter a Janke, 2006).

S použitím české verze byla na vzorku 130 seniorů ve věku 60-75 let (55 mužů, 75 žen) zjištěna poněkud nižší vnitřní konzistence celkových strategií a pozitivních podtypů 
v rozmezí 0,65 - 0,84, hodnoty pro jednotlivé škály nejsou bohužel uváděny (Kravcová, 2015).

\section{Validita}

Na základě teoretických předpokladů byl v rámci standardizační studie (Weyers, Ising a Janke, 2005) na německém vzorku 246 osob (122 žen, 124 mužů) ověřován vzájemný vztah jednotlivých škál a následně faktorová struktura, obojí pro muže a ženy zvlášt'. Většina korelací škál se pohybovala do hodnoty 0,4 , hodnoty větší než 0,5 se vyskytly mezi škálami 3. podtypu pozitivních strategií - Strategie kontroly (Kontrola situace, Kontrola reakcí a Pozitivní sebeinstrukce) a pak mezi škálami negativních strategií (Úniková tendence, Perseverace, Rezignace a Sebeobviňování). Mezi škálami Úniková tendence a Rezignace byl pak nalezen nejtěsnější vztah s hodnotou 0,74 , lze tak uvažovat o tom, zda by nebylo na místě tyto škály sloučit, popřípadě se zamyslet i nad potřebou rozlišovat negativní strategie a strategie kontroly na několik škál.

Na stejném vzorku byla poté zkoumána faktorová struktura metodou hlavních komponent s rotací Varimax a extrakcí podle metody hlavních os (Weyers, Ising a Janke, 2005). Za adekvátní považují autoři studie pětifaktorové řešení, které vykazovala i předchozí verze testu SVF 120. Pět faktorů vysvětlilo 75,9 \% rozptylu, 1. faktor zahrnuje negativní strategie plus nezařazenou škálu Vyhnutí se, faktory 2-4 pak odpovídají jednotlivým podtypům pozitivních strategií (Strategie přehodnocení a devalvace, Strategie odklonu a Strategie kontroly), poslední pátý faktor sytí nezařazenou škálu Potřeba sociální opory. Tato struktura byla pozorována i pro muže a ženy zvlášt'. Tento výsledek by bylo možné pojímat jako důkaz o validitě struktury dotazníku, s výjimkou samostatných škál Vyhýbání se a Potřeba sociální opory odpovídají faktory zařazení škál v rámci metody. Ovšem vzhledem k tomu, že není jisté, jak dotazník vznikal a zda nebyla faktorová analýza součástí jeho konstrukce, nelze tomuto důkazu přisuzovat př́lišnou váhu. Weyers, Ising a Janke (2005) zmiňují, že výběr 13 škál z původní verze byl proveden mimo jiné na základě faktorové struktury. Autoři navíc nezdůvodňují využití modelu s nekorelovanými faktory, vzhledem k vzájemné korelaci jednotlivých škál dotazníku by bylo spíše nasnadě předpokládat mezi faktory vztah. Faktorové řešení není autory dále komentováno, vyjma odkazu na shodnou strukturu starší verze dotazníku. Autoři se nepokoušejí vysvětlit sycení škály Vyhýbání se faktorem negativních strategií, ačkoliv se ukázala mít vyšší náboj než 2 škály „čistě“ negativních strategií a ačkoliv takový výsledek příliš neodpovídá jejich pojímání škály jako dvojznačné (žádný faktor pozitivních strategií škálu výrazněji nesytil). Autoři také nevysvětlují význam 5. faktoru, který sytí pouze škálu Potřeba sociální opory, která jinak nebyla sycena ani negativním, ani pozitivními faktory. Význam škály v rámci dotazníku a vliv této strategie na zvládání stresu je tak poněkud záhadou. Faktorovou strukturu originální verze testu ukazuje Tabulka 1.

Faktorová struktura byla zkoumána i na českém vzorku s českou adaptací dotazníku. Balcar, Trnka a Kuška (2011) provedli explorační faktorovou analýzu s rotací Oblimin na vzorku 187 vysokoškolských studentů (85 mužů, 102 žen) ve věku 19-34 let, přičemž 
srovnávali možnou tř́í, čtyř a pětifaktorovou strukturu. Za nejadekvátnější považovali čtyřfaktorovou strukturu podle inspekce vlastních hodnot a sutinového diagramu, $v$ potaz byly přitom brány jen náboje větší než 0,4. První faktor byl nazván Zhroucení psychických obran, který pozitivně sytil škály negativních strategií a nezařazenou škálu Potřeba sociální opory a negativně první pozitivní podtyp Strategie přehodnocení a devalvace. Druhý faktor byl nazván Aktivní konfrontace problému a sytil pozitivně podtyp Strategie kontroly a škálu Vyhýbání se. Třetí faktor - Aktivní vyhýbání se situaci sytil pozitivně škály Odklon, Úniková tendence, Náhradní uspokojení a Vyhýbání se. Faktor 4 je pak nazván Psychologická kompenzace a sytí negativně škály Náhradní uspokojení a Potřeba sociální opory a pozitivně škálu Podhodnocení. Odlišná kombinace škál v rámci faktorů koresponduje s nejasným teoretickým zázemím dotazníku, především s tím, že není vysvětlen vztah jednotlivých škál vůči sobě. Faktorovou strukturu české adaptace ukazuje Tabulka 2.

\section{Tabulka 1}

Faktorová struktura SVF-78 prezentovaná v manuálu (pocházející ze standardizace Weyerse, Isinga a Jankeho, 2005) - sycení samostatných škál Vyhýbání se a Potřeba sociální opory př́liš neodpovídá teorii

\begin{tabular}{|l|l|}
\hline Faktory & Sycené škály \\
\hline 1. faktor & $\begin{array}{l}\text { V̌̌echny škály negativních strategií, škála } \\
\text { Vyhýbání se }\end{array}$ \\
\hline 2. faktor & Škály Strategií kontroly \\
\hline 3. faktor & Škály Strategií přehodnocení a devalvace \\
\hline 4. faktor & Škály Strategií odklonu \\
\hline 5. faktor & Potřeba sociální opory \\
\hline
\end{tabular}

\section{Tabulka 2}

Faktory české adaptace SVF-78 podle Balcara, Trnky a Kušky (2011), neodpovídající struktuře uvedené v manuálu

\begin{tabular}{|l|l|}
\hline Faktory & Sycené škály \\
\hline 1. faktor - Zhroucení psychických obran & $\begin{array}{l}\text { Pozitivně: Škály negativních strategií, } \\
\text { Potřeba sociální opory } \\
\text { Negativně: Škály Strategií podhodnocení } \\
\text { a devalvace }\end{array}$ \\
\hline 2. faktor - Aktivní konfrontace problému & $\begin{array}{l}\text { Pozitivně: Škály Strategie kontroly, } \\
\text { Vyhýbání se }\end{array}$ \\
\hline 3. faktor - Aktivní vyhýbání se situaci & $\begin{array}{l}\text { Pozitivně: Odklon, Únikové tendence, } \\
\text { Náhradní uspokojení, Vyhýbání se }\end{array}$ \\
\hline 4. faktor - Psychologická kompenzace & $\begin{array}{l}\text { Pozitivně: Podhodnocení } \\
\text { Negativně: Náhradní uspokojení, } \\
\text { Potřeba sociální opory }\end{array}$ \\
\hline
\end{tabular}


Důkazy o konstruktové ani kriteriální validitě nejsou příliš dostupné. Weyers, Ising a Janke (2005) sice uvádějí, že původní dotazník SVF 120 vykazoval konzistentně konstruktovou validitu v podobě faktorové struktury, konvergentní a diskriminantní validity a externí validitu vyvozenou ze vztahů s jinými škálami měřícími strategie zvládání stresu, k původním článkům, na které odkazují, se mi však nepodařilo dostat.

Kravcová (2015) zkoumala na vzorku 130 českých seniorů souvislost testu s extraverzí a neuroticismem ze zkrácené verze NEO-PI - NEO-FFI. Extraverze se zde ukázala mít slabý pozitivní vztah se všemi podtypy pozitivních strategií $(r=0,19-0,20, \mathrm{p}<0,05)$, první dva pozitivní podtypy (Strategie podhodnocení a odmítání viny a Strategie odklonu) se také ukázaly mít slabý negativní vztah s neuroticismem ( $\mathrm{r}=-0,19 \mathrm{a}-0,17, \mathrm{p}<0,05)$. Tento výsledek lze pojímat jako podpoření předpokladu o relativní nezávislosti strategií s osobnostními charakteristikami. Naopak negativní strategie vykazovaly silnější vztah s neuroticismem $(r=0,48, p<0,01)$, což napovídá tomu, že mezi oběma konstrukty bude zásadnější souvislost, než autoři metody předpokládali.

\section{Normy}

Metoda byla standardizována na německém vzorku 246 osob, 122 žen a 124 mužů ve věku 20-64 let, většina osob měla středoškolské vzdělání či vzdělání s maturitou, malé množství převážně starších respondentů pak pouze vzdělání základní. Žádné bližší informace o vzorku však nejsou v manuálu uvedeny. Z publikované standardizační studie (Weyers, Ising a Janke, 2005) je zřejmé, že respondenti byli získáni příležitostným výběrem (studenti psychologického kurzu, každý distribuoval dotazník 5 lidem). Uživatel však nemá žádné údaje o relevantních demografických proměnných jako je etnicita či povolání, nemůže si tak být jist reprezentativností vzorku vzhledem k populaci. Autoři se přitom domnívali, že výsledky budou podobné jako pro vzorek ze standardizace předchozí verze SVF 120 vzhledem k identickým škálám, je tak možné, že podrobnější informace o standardizaci lze nalézt v manuálu této verze.

Výsledky standardizace jsou uváděny ve formě průměrů a směrodatných odchylek zvlášt' pro pohlaví a pro 3 věkové skupiny: 20-34 let, 35-49 let, 50-64 let. Na základě výsledků analýzy rozptylu byl pozorován vztah pohlaví a věku, muži skórovali výše na škálách Podhodnocení a Odmítání viny (tedy 1. podtyp pozitivních strategií), ženy dosahovaly celkově vyšších hodnot $\mathrm{v}$ rámci negativních strategií, konkrétně na škálách Únikové tendence, Perseverace, Rezignace a Sebeobviňování a dále pak na samostatné škále Potřeba sociální opory, velikosti účinku však nejsou uváděny. Co se týče vlivu věku, nejmladší skupina (20-34 let) dosahovala vyšších skórů na škálách Náhradní uspokojení, Potřeba sociální opory a Sebeobviňování, dále pak v rámci celkových negativních strategií a v podtypu pozitivní strategie 2 - Odklon, nejstarší skupina (50-64 let) pak dosahovala vyšších skórů na škále Vyhýbání se, což autoři přičítají možné adaptivní facilitaci s přibývajícím věkem. 
České normy testu existují pouze pro počítačově administrovanou metodu, pro metodu tužka-papír, jež je předmětem recenze, jsou k dispozici pouze normy zahraniční.

\section{Závěr}

Ačkoliv je dotazník strategií zvládání stresu označován za nejčastěji používanou metodu zvládání stresu v Německu (Mayers, Ising a Janke, 2005), nepodařilo se mi najít větší množství studií v anglickém jazyce, které by s dotazníkem pracovaly. Výzkumy zvládání stresu často využívaly některou $\mathrm{z}$ jiných existujících metod a $\mathrm{v}$ případě, že používaly některou z verzí SVF, se většinou nevěnovaly jejím psychometrickým vlastnostem. Několik studií, na které autoři odkazovali v manuálu a které mi přišly dosti zásadní pro porozumění metodě, obzvláště její konstrukci a teoretickým východiskům, jsou k dostání pouze zpoplatněné.

Manuál je celkově velmi stručný a neobsahuje mnohé relevantní informace. Autoři přitom často odkazují na manuál předchozí verze testu - SVF 120. Domnívám se, že to není př́liš št'astné řešení, pro lepší porozumění teorii i způsobu vývoje by uživatel potřeboval manuál starší verze a nelze očekávat, že jej vlastní či že je celkově s předchozí verzí metody blíže seznámen. Předpoklad znalosti předchozí verze mi přijde ještě méně oprávněný vzhledem $\mathrm{k}$ tomu, že se nejedná o univerzálně známou a široce využívanou metodu (minimálně ne mimo německy mluvící země), u které by mohl být podobný přístup více pochopitelný. Dalo by se tak říci, že jako jeden z nejzásadnějších nedostatků metody vnímám nedostupnost informací.

Na metodě lze ocenit dobrou reliabilitu škál i strategií odhadovanou různými způsoby Cronbachovo $\alpha$, split-half reliabilita a test-retest reliabilita. Naopak vytknout je třeba nedostatečné teoretické zázemí (zmiňovány jsou pouze základní předpoklady pojetí stresu a zběžné nastínění významu škál), absenci popisu vývoje metody, nedostatečné informace o spíše skromnějším standardizačním vzorku a otázka jeho reprezentativnosti, nejasný vztah jednotlivých škál dotazníku související s jeho faktorovou strukturou a také neprokázanou validitu nástroje. V kontextu české adaptace jsou pak dosti problematické chybějící informace o překladu a neexistence tuzemských norem.

Co se týče samotného obsahu dotazníku, některé formulace v rámci jedné škály mohou dle mého názoru zachycovat poněkud odlišné věci (přání/plánování vs. realita), což může znesnadnit interpretaci. Např́íklad v rámci škály Kontrola situace, která je řazena k pozitivním strategiím, se vyskytují položky tázající se jednak na plánování kontroly situace a jednak na reálnou aktivní snahu situaci kontrolovat. Domnívám se, že pouhé plánování nemusí vypovídat o reálném využívání této strategie a nemusí také přispívat k efektivnímu zvládání stresu. Naopak by mohlo nabývat podoby ulpívavého myšlení (škála Perseverace) a tudíž být spíše kontraproduktivní strategií. To může umocňovat celkovou nejasnost ohledně jednotlivých škál a jejich vzájemných vztahů, stejně jako jejich zařazení do pozitivních nebo negativních strategií. 


\section{Shrnutí}

Výtek je poměrně mnoho a nejsou zanedbatelné, domnívám se proto, že v současné podobě není metoda vhodná pro autory zamýšlené účely - pro srovnávání skupin v oblasti psychologie zdraví, psychologie nemoci a pracovní psychologie, individuální diagnostiku sami autoři nedoporučují kvůli nedostatku validizačních studií. Obzvláště užití v pracovní psychologii mi přijde problematické, vzhledem k nejasnému teoretickému základu a absenci validizačních studií by byla práce s metodou v tomto kontextu neoprávněná a neetická. Sami autoři navíc upozorňují na nebezpečí záměrného zkreslování výsledků a metoda neobsahuje žádný lži-skór, její využití by tak nemuselo mít ani přílišnou výpovědní hodnotu. $V$ českém prostředí jsou navíc problémem zahraniční normy. Metodu tak doporučuji raději pouze pro výzkum, minimálně do doby, než bude stát na pevnějších teoretických základech a bude prokázána její validita. Zajímavou cestou v tomto směru může být př́stup Balcara, Trnky a Kušky (2011), kteří se nalezenou faktorovou strukturu české verze dotazníku pokusili poměrně úspěšně interpretovat pomocí Lazarusova transakčního modelu stresu.

\section{Literatura}

Balcar, K., Trnka, R., \& Kuška, M. (2011). How Many Ways to Deal With Stress? Stress coping factors in the SVF 78. Activitas Nervosa Superior, 53(1-2), 27-34.

Ising, M., Weyers, P., Reuter, M., \& Janke, W. (2006). Comparing two approaches for the assessment of coping: Part II. Differences in stability in time. Journal of Individual Differences, 27(1), 15-19.

Janke, W. \& Erdmann, G. (2003). Strategie zvládání stresu. Praha: Testcentrum.

Kravcová, M. (2015). Selected personality characteristics and coping strategies as predictors of life satisfaction of the eldres. E-psychologie [online], 9(4), 12-23.

Weyers, P., Ising, M., \& Janke, W. (2005). Effects of imagined stress intensity on responses in a stress coping inventory. Anxiety, Stress \& Coping, 18(2), 117-130.

Weyers, P., Ising, M., Reuter, M., \& Janke, W. (2005). Comparing two approaches for the assessment of coping: Part I. Psychometric properties and intercorrelations. Journal of Individual Differences, 26(4), 207-212. 


\author{
EFPA \\ STANDING COMMITTEE ON \\ TESTS AND TESTING (SCTT)
}

Příloha ke Zprávě předsedy, 2005

MODEL RECENZE PODLE EFPA PRO POPIS

A HODNOCENÍ PSYCHOLOGICKÝCH TESTŮ

FORMULÁŘ RECENZE TESTU A POZNÁMKY PRO RECENZENTY

Verze 3.42

Lokální úprava pro časopis Testforum

ISSN 1805-9147 


\section{MODEL RECENZE PODLE EFPA PRO POPIS \\ A HODNOCENÍ PSYCHOLOGICKÝCH TESTŮ \\ FORMULÁŘ RECENZE TESTU A POZNÁMKY PRO \\ RECENZENTY ${ }^{1}$}

Toto je lokální úprava dokumentu pro účely publikace v časopise Testfórum.

Originální český překlad je k dispozici na stránkách EFPA

(www.efpa.eu/download/505cd9db4144ecb16174087909c9cd6d).

Původní verzi sestavil a uspořádal Dave Bartram

Doplnili a revidovali Patricia Lindley, Dave Bartram a Natalie Kennedy v dubnu $2004^{2}$

Současná verze 3.42: květen 2005

Český překlad: Tomáš Urbánek

Od uživatelů tohoto dokumentu a jeho obsahu žádá EFPA, aby uznali tento zdroj prostřednictvím následujícího textu:

"Kritéria pro recenzi testu podle EFPA do značné míry vychází z formy a obsahu kritérií pro recenze testů Britské psychologické společnosti (BPS) a kritérií vytvořených Komisí pro testové záležitosti (COTAN) Holandské asociace psychologů (NIP). Dave Bartram a Patricia Lindley původně vyvinuli kritéria BPS a recenzní procedury pro UK Employment Service a později rozšírili jejich používání pro celou BPS. Arne Evers připravil k vydání nizozemský system posuzování kvality testů.

EFPA je vděčná BPS a NIP za svolení použít jejich kritéria jako základ pro vytvoření evropského modelu. EFPA je také vděčná Davu Bartramovi, Arnu Eversovi a Patricii Lindley za jejich přispění $k$ vývoji tohoto modelu. Veškerá intelektuální vlastnická práva původních kritérií podle BPS a NIP jsou nadále uznávána a náleží těmto orgánům."

\footnotetext{
1 Tento dokument byl vytvořen z několika zdrojů, včetně Hodnotícího formuláře pro recenzi testu používaného v BPS (NPAL a Řídící komise pro testové standardy při BPS - Steering Committee on Test Standards), Španělského dotazníku pro hodnocení psychometrických testů (Španělská psychologická asociace) a Systému pro posuzování kvality testu (Komise pro testování Holandské asociace psychologů). Některé části byly adaptovány se svolením z dokumentu: BPS Books Reviews of Level B Assessment Instruments for use in Occupational Assessment, Notes for Reviewers: Version 3.1. December 1998: Copyright (C) NPAL, 1989, 1993, 1998.

2 Současná verze je spojením dvou oddělených dokumentů (Formuláře recenze a Poznámek pro recenzenty). Obsah byl navíc uspořádán a doplněn na základě jeho používání recenzenty online testů v BPS.
} 


\section{Č́st 1:}

Popis nástroje: Obecné informace a klasifikace

\begin{tabular}{|c|c|c|}
\hline \multicolumn{3}{|c|}{ FPA 3.2 reference } \\
\hline & Recenzent 1: & Bc. Gabriela Binderová \\
\hline & Recenzent 2: & \\
\hline & Konzultující editor: & Mgr. Jaroslav Gottfried \\
\hline & Vedoucí editor: & Mgr. Hynek Cígler, Ph.D. \\
\hline & $\begin{array}{l}\text { Vedoucí editor aktualizace: } \\
\text { (pouze v př́padě aktualizací) }\end{array}$ & \\
\hline & $\begin{array}{l}\text { Editor aktualizace: } \\
\text { (pouze v př́padě aktualizací) }\end{array}$ & \\
\hline & Datum vzniku této recenze: & 5. 1.2021 \\
\hline 1.1 & Název nástroje (lokální verze): & Strategie zvládání stresu \\
\hline & Zkrácená verze názvu testu: & SVF-78 \\
\hline 1.2 & $\begin{array}{l}\text { Původní název testu (pokud je lokální } \\
\text { verze adaptací): }\end{array}$ & Stressverarbeitungsfragebogens \\
\hline 1.4 & Autoři původního testu: & Wilhelm Jankfe, Gisela Erdmann \\
\hline 1.3 & Autoři lokální adaptace: & Josef Švancara \\
\hline 1.7 & Lokální distributor/vydavatel testu: & Hogrefe - Testcentrum \\
\hline 1.8 & $\begin{array}{l}\text { Vydavatel původní verze testu (pokud je } \\
\text { jiný než současný distributor/vydavatel): }\end{array}$ & Hogrefe-Verlag \\
\hline 1.9 .1 & Datum vydání současné revize/vydání: & 2003 \\
\hline 1.9 .2 & $\begin{array}{l}\text { Datum vydání adaptace pro lokální } \\
\text { užívání: }\end{array}$ & 2003 \\
\hline 1.9 .3 & Datum vydání původního testu: & 2002 \\
\hline
\end{tabular}




\section{Obecný popis nástroje}

Dotazník Strategií zvládání stresu SVF 78 je vícedimenzionální sebeposuzovací inventář zachycující individuální tendence pro nasazení různých způsobů reagování na stres v zátěžových situacích. Byl vytvořen zkrácením původní německé verze SVF120, česká adaptace byla vytvořena pouze pro zkrácenou verzi v roce 2003. Jedná se o metodu typu papír tužka, v českém prostředí existuje i počítačová verze, ta však není předmětem recenze.

Test je určen pro dospělou populaci, autoři jej doporučují pro srovnávání skupin vystavených různým formám zátěže $\mathrm{v}$ různých oblastech, jako je psychologie zdraví a nemoci a pracovní psychologie. Interpretace výsledků v rámci individuální psychologické diagnostiky je dle autorů předmětem dalš́no zkoumání validity. $\mathrm{V}$ př́padě individuální diagnostiky autoři upozorňují na chybovost měření a možnou významnou odchylku získaného skóru od pravého, dále pak na problematiku aplikace výsledků na konkrétní zátěžové situace a možnou neochotu respondenta být sdílný.

Metoda obsahuje příručku, dotazník, vyhodnocovací list a testový profil. Součástí příručky jsou tabulky norem a převodů na Tskóry pro muže a ženy zvlášt'. Dotazník se skládá z 13 škál: Podhodnocení, Odmítání viny, Odklon, Náhradní uspokojení, Kontrola situace, Kontrola reakcí, Pozitivní sebeinstrukce, Potřeba sociální opory, Vyhýbání se, Úniková tendence, Perseverace, Rezignace, Sebeobviňování. Každá škála obsahuje 8 položek (celkem 78 položek), přičemž každá položka začíná stejným výrokem: Když jsem něčím nebo někým poškozen(a), vnitřně rozrušen(a), nebo vyveden(a) z míry, načež je vždy věta doplněna určitým tvrzením, jehož subjektivní pravdivost hodnotí respondenti na pětibodové Likertově škále (vůbec ne - velmi pravděpodobně). Jednotlivé škály jsou přiřazovány bud' k pozitivním, nebo negativním strategiím, přičemž pozitivní strategie lze rozdělit na 3 podtypy Strategie přehodnocení a devalvace, Strategie odklonu a Strategie kontroly.

\section{Část 2: \\ Klasifikace}

\begin{tabular}{|c|c|c|}
\hline $\begin{array}{ll}1.10 .1 \\
\end{array}$ & Obsahová doména & $\begin{array}{ll} & \text { Školní schopnosti } \\
\square & \text { Všeobecné schopnosti } \\
\square & \text { Verbální schopnosti } \\
\square & \text { Numerické schopnosti } \\
\square & \text { Prostorové schopnosti } \\
\square & \text { Neverbální schopnosti } \\
\square & \text { Rychlost vnímání } \\
\square & \text { Pamět' } \\
\square & \text { Manuální zručnost } \\
\bigotimes & \text { Osobnost - Rys } \\
\square & \text { Osobnost - Typ } \\
\square & \text { Osobnost - Stav } \\
\bigotimes & \text { Kognitivní styly } \\
\bigotimes & \text { Motivace } \\
\square & \text { Hodnoty } \\
\square & \text { Zájmy } \\
\square & \text { Přesvědčení } \\
\square & \text { Poruchy a patologie } \\
\square & \text { Skupinové procesy } \\
\square & \text { Rodina } \\
\square & \text { Organizace, její fungování, agregovaná } \\
& \text { měření, klima atd. } \\
\square & \text { Školní nebo výchovné funkce } \\
\square & \text { Jiné: }\end{array}$ \\
\hline
\end{tabular}




\begin{tabular}{|c|c|c|}
\hline 1.10 .2 & $\begin{array}{l}\text { Zamýšlená(é) nebo hlavní oblast(i) } \\
\text { použití. }\end{array}$ & $\begin{array}{ll}\square & \text { Klinická psychologie } \\
\square & \text { Neuropsychologie } \\
\square & \text { Forenzní psychologie } \\
\square & \text { Psychologie výchovy a vzdělávání } \\
\square & \text { Psychologie práce a personalistika } \\
\square & \text { Poradenství, doporučení, vedení a volba } \\
& \text { povolání } \\
\bigotimes & \text { Psychologie zdraví, životní styl a životní } \\
& \text { spokojenost } \\
\square & \text { Sporty a volný čas } \\
\square & \text { Jiné: }\end{array}$ \\
\hline 1.10 .3 & $\begin{array}{l}\text { Zamýšlený způsob použití } \\
\text { (podmínky, za jakých byl nástroj } \\
\text { standardizován a validizován) }\end{array}$ & $\begin{array}{l}\text { Nesupervidovaná administrace bez } \\
\text { kontroly nad identitou respondenta a bez } \\
\text { úplné kontroly nad podmínkami } \\
\text { administrace (např. volně přístupný test } \\
\text { na internetu, test dostupný ke koupi v } \\
\text { knihkupectví). } \\
\text { Kontrolovaný nesupervidovanou } \\
\text { administrcí. Kontrola nad podmínkami } \\
\text { (čas atd.) a určitá kontrola nad identitou } \\
\text { uživatele testu (např. testy } \\
\text { administrované přes internet, ale pouze } \\
\text { známým osobám - př́ístup omezený } \\
\text { heslem). } \\
\text { Supervidovaná a kontrolovaná } \\
\text { administrace. Administrace testu pod } \\
\text { kontrolou kvalifikovaného adminitrátora } \\
\text { nebo dohlížitele. } \\
\text { Řízená administrace. Administrace testu } \\
\text { prováděná pouze přes určená testovací } \\
\text { centra (např. programy hodnocení licencí } \\
\text { a certifikace). }\end{array}$ \\
\hline 1.10 .4 & $\begin{array}{l}\text { Popis populací, pro které je test } \\
\text { určen: }\end{array}$ & Dospělá populace (normy pro věk 20 - 64 let) \\
\hline 1.10 .5 & $\begin{array}{l}\text { Počet škál a krátký popis } \\
\text { proměnné nebo proměnných } \\
\text { měřených nástrojem }\end{array}$ & $\begin{array}{l}13 \text { škál: Podhodnocení, Odmítání viny, } \\
\text { Odklon, Náhradní uspokojení, Kontrola } \\
\text { situace, Kontrola reakcí, Pozitivní } \\
\text { sebeinstrukce, Potřeba sociální opory, } \\
\text { Vyhýbání se, Úniková tendence, Perseverace, } \\
\text { Rezignace, Sebeobviňování. } \\
\text { Škály lze dále sloučit do oblastí Pozitivní } \\
\text { stategie a Negativní strategie, škály Potřeba } \\
\text { sociální opory a Vyhýbání se pak stojí } \\
\text { samostatně. }\end{array}$ \\
\hline
\end{tabular}




\begin{tabular}{|c|c|c|}
\hline 1.11 & Formát položek & $\begin{array}{ll}\square & \text { Otevřený } \\
\square & \text { Mnohonósobná volba, alternativy na } \\
& \text { stejné škále } \\
\square & \text { Bipolární adjektiva } \\
\otimes & \text { Likertovy ratingy (škály) } \\
\square & \text { Nucená volba, alternativy na smíšených } \\
\text { škálách (ipsativní) - vysvětlení viz } \\
\text { Poznámky } \\
\square \text { Mnohonásobná volba, alternativy na } \\
\text { smíšných škálách (ipsativní) - } \\
\text { vysvětlení viz Poznámky } \\
\square \text { Sady párů adjektiv (sémantický } \\
\text { diferenciál), smíšené škály (ipsativní) } \\
\square \quad \text { Jiné: }\end{array}$ \\
\hline 1.12 & Počet položek testu: & 78 (6 položek na škálu) \\
\hline 1.13 & Způsob(y) administrace: & $\begin{array}{ll} & \text { Interaktivní individuální administrace } \\
\otimes & \text { Supervidovaná skupinová administrace } \\
\square & \text { Počítačová lokálně nainstalovaná } \\
& \text { aplikace - pod supervizí/dohledem } \\
\square & \text { Počítačová aplikace na webu - pod } \\
\text { supervizí/dohledem } \\
\square & \text { Počítačová lokálně nainstalovaná } \\
\text { aplikace - bez supervise/testování sebe } \\
\square \\
\text { Počítačová aplikace na webu - bez } \\
\text { supervize/testování sebe } \\
\square & \text { Jiné: }\end{array}$ \\
\hline 1.14 & Způsob odpovídání: & $\begin{array}{ll}\square & \text { Ústní rozhovor } \\
\bigotimes & \text { Papír a tužka } \\
\square & \text { Manuální operace } \\
\square & \text { Na počítači } \\
\square & \text { Jiné: }\end{array}$ \\
\hline
\end{tabular}




\begin{tabular}{|c|c|c|}
\hline 1.15 & 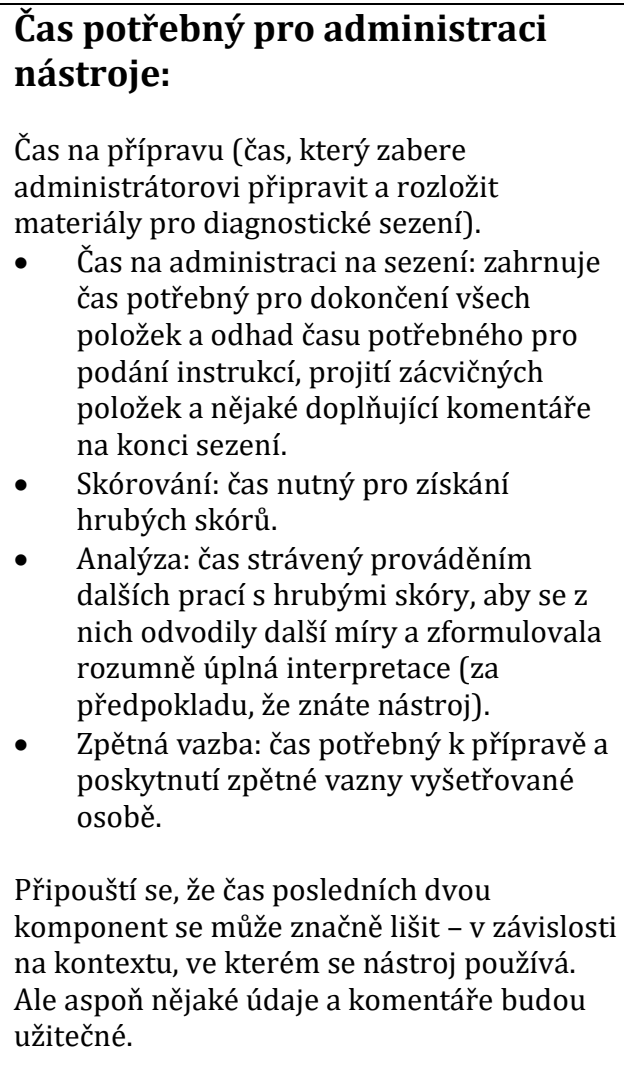 & $\begin{array}{l}\text { Příprava: } 5 \text { minut } \\
\text { Administrace: } 10-15 \text { minut } \\
\text { Skórování: } 10 \text { minut } \\
\text { Analýza: } 30 \text { minut } \\
\text { Zpětná vazba: } 30 \text { minut } \\
\text { Autoři testu uvádějí pouze přibližnou } \\
\text { dobu administrace, zbytek časových } \\
\text { údajů je přibližně odhadnut z osobní } \\
\text { zkušenosti s metodou. }\end{array}$ \\
\hline 1.16 & $\begin{array}{l}\text { Jsou } k \text { dispozici různé formy } \\
\text { nástroje? }\end{array}$ & $\begin{array}{l}\mathrm{V} \text { českém prostředí existuje krom } \\
\text { papírové metody také počítačová forma. } \\
\mathrm{V} \text { zahraničí je } \mathrm{k} \text { dispozici také původní } \\
\text { delší verze SVF120. }\end{array}$ \\
\hline
\end{tabular}

\section{Část 3:}

\section{Měření a skórování}

\begin{tabular}{|c|c|c|}
\hline 1.17 & Procedura skórování testu: & 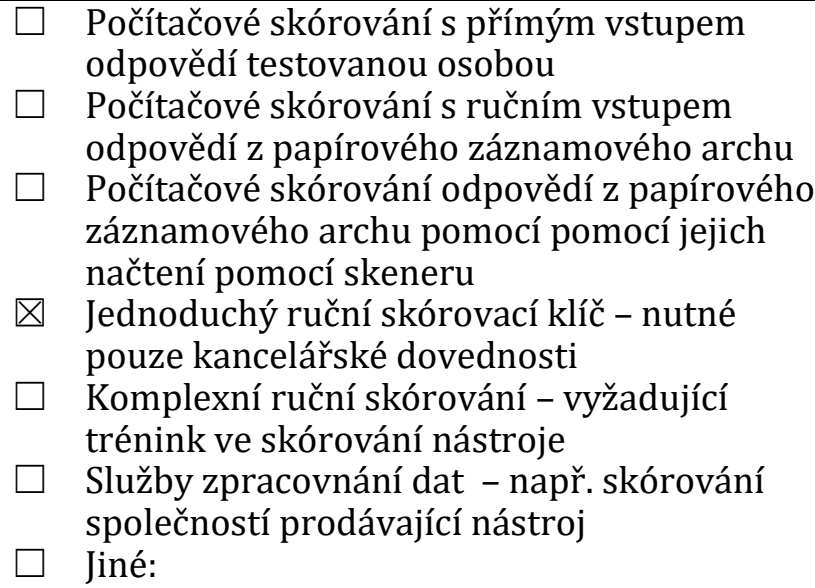 \\
\hline
\end{tabular}




\begin{tabular}{|c|c|c|}
\hline 1.18 & Skóry: & $\begin{array}{l}\text { Vyhodnocování se provádí součtem skórů } \\
\text { v rámci jednotlivých škál. Takto vzniklé hrubé } \\
\text { skóry se dále převádí na T-skóry pomocí } \\
\text { přiložených tabulek, které jsou převzaté } \\
\text { z původní verze SVF } 120 \text {. Průměrem součtu } \\
\text { hrubých skórů určitých škál se dále získá hrubý } \\
\text { skór celkových pozitivních a negativních } \\
\text { strategií, který je opět možné převést na T-skóry. }\end{array}$ \\
\hline 1.19 & $\begin{array}{l}\text { Transformace skóru na standardní } \\
\text { skóry: }\end{array}$ & $\begin{array}{ll}\square & \begin{array}{l}\text { Normalizovaná - skóry se získají použitím } \\
\text { normalizační tabulky }\end{array} \\
\square & \text { Nenormalizovaná - skóry se získají lineární } \\
\text { transformací }\end{array}$ \\
\hline 1.20 & Použité škály & 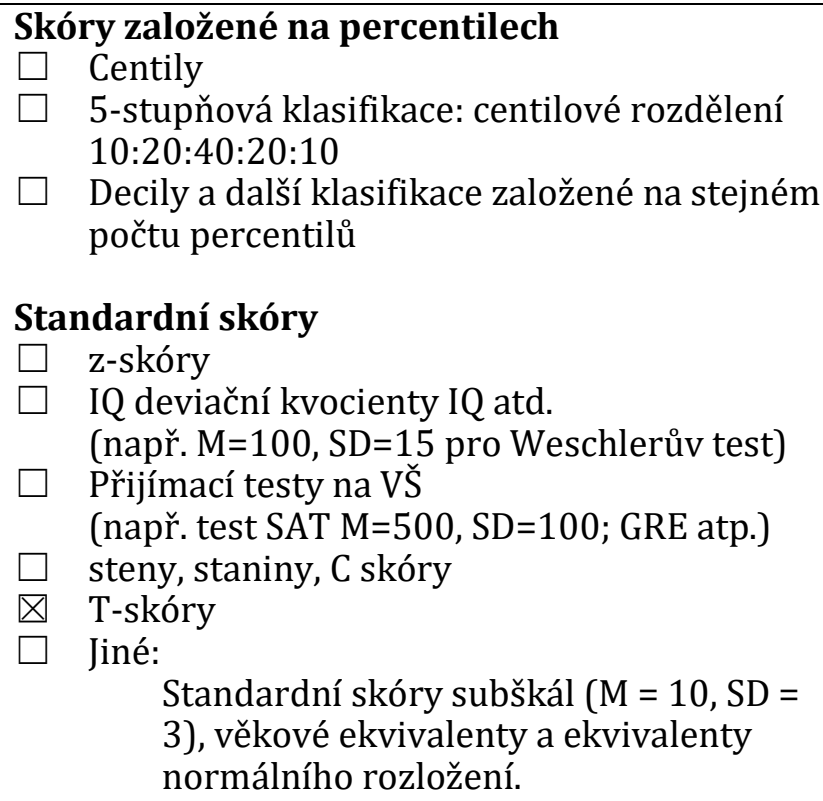 \\
\hline
\end{tabular}

Č́ást 4:

Počítačově generované zprávy

Toto je čistě popisné. Hodnocení zpráv bude součástí části recenze nazvané Hodnocení.

\begin{tabular}{|l|l|l|}
\hline 1.21 & $\begin{array}{l}\text { Jsou počítačově generované zprávy } \mathbf{k} \\
\text { dispozici s nástrojem? }\end{array}$ & $\square$ Ano \\
& $\bigotimes \quad \mathrm{Ne}$ \\
\hline
\end{tabular}

\section{Č́st 5:}

\section{Nabídka, podmínky a náklady}

Tato část definuje, co vydavatel poskytne, komu, za jakých podmínek a za jaké ceny. Definuje podmínky kladené dodavatelem a týkající se toho, kdo smí a kdo nesmí získat materiál nástroje. Pokud jedna z možností neodpovídá podmínkám nabídky, doplňte popis relevantních podmínek. 


\begin{tabular}{|c|c|c|}
\hline 1.23 & $\begin{array}{l}\text { Dokumentace poskytovaná } \\
\text { distributorem jako součást } \\
\text { testového balíku }\end{array}$ & 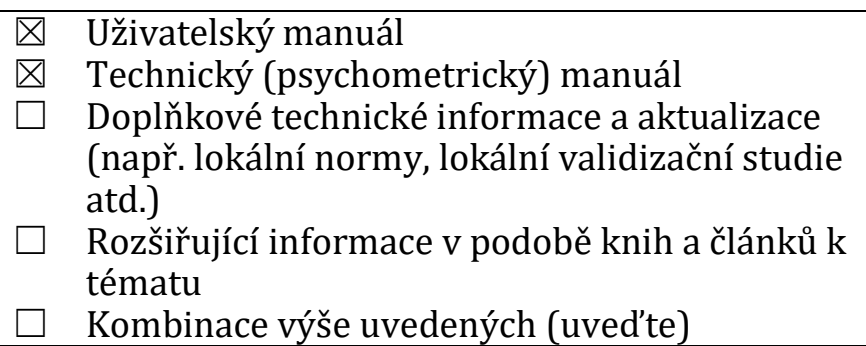 \\
\hline 1.24 & Metody publikace & $\begin{array}{ll} & \text { Papír } \\
\square & \text { PC - Diskety } \\
\square & \text { PC - CD/ROM } \\
\square & \text { Download z internetu } \\
\square & \text { Živý internet (nástroj pracuje v internetovém } \\
\text { prohlížeči) } \\
\square \text { Jiné: }\end{array}$ \\
\hline 1.25 .1 & $\begin{array}{l}\text { Počáteční náklady. } \\
\text { Cena kompletní sady materiálů (v̌̌echny manuály a } \\
\text { dalš́s material nutný k aspoň jedné zkušební } \\
\text { administraci). Kolik uchazečú lze vyšetřovat pomocí } \\
\text { materiálu získaných za počáteční náklady, kde tyto } \\
\text { náklady zahrnují materially pro opakované vyšetř́ní. }\end{array}$ & $\begin{array}{l}\text { Úplný testový soubor (př́íručka, } 40 \text { ks dotazníků, } 40 \\
\text { ks vyhodnocovacích listů, } 40 \text { ks testových profilů) - } \\
1490 \text { Kč. }\end{array}$ \\
\hline 1.25 .2 & Opakující se náklady: & $\begin{array}{l}40 \text { ks dotazníků } 600 \text { Kč } \\
40 \text { ks vyhodnocovacích listů } 220 \text { Kč } \\
40 \text { ks testových profilů } 220 \text { Kč }\end{array}$ \\
\hline 1.26 .1 & $\begin{array}{l}\text { Ceny za zprávy generované } \\
\text { softwarem nainstalovaným } \\
\text { uživatelem: }\end{array}$ & \\
\hline 1.26 .2 & $\begin{array}{l}\text { Ceny za vyhotovení zprávy zaslené } \\
\text { prostřednictvím pošty/faxu: }\end{array}$ & \\
\hline 1.26 .3 & $\begin{array}{l}\text { Ceny za vyhotovení zprávy zaslené } \\
\text { prostřednictvím internetové služby: }\end{array}$ & \\
\hline 1.27 & $\begin{array}{l}\text { Ceny za další služby a zpracování } \\
\text { dat: opravy nebo vývoj } \\
\text { automatických zpráv: }\end{array}$ & \\
\hline 1.28 & 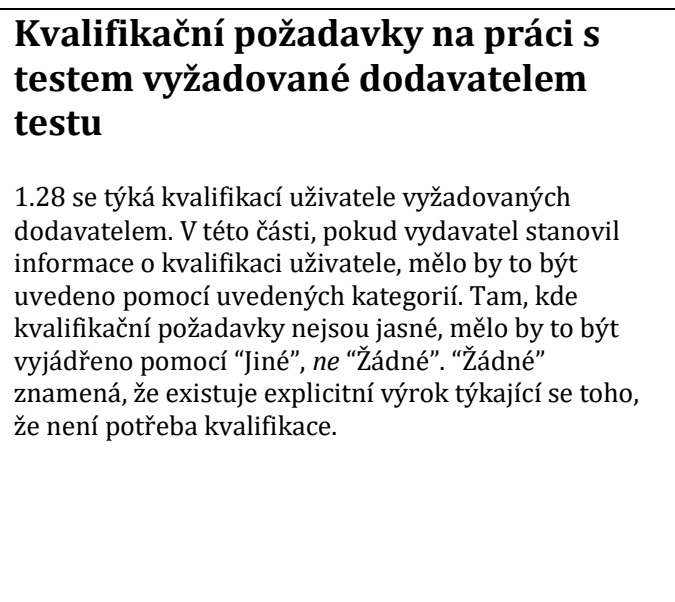 & $\begin{array}{l}\square \quad \text { Žádné } \\
\square \quad \text { Oprávnění (certifikát) pro specifický test } \\
\square \quad \text { Oprávnéní (certifikát) pro obecné výkonové } \\
\text { testy: i. e. míry maximálního výkonu ve } \\
\text { schopnostech } \\
\square \quad \begin{array}{l}\text { Potvrzení v testování obecných schopností a } \\
\text { dovedností: míry maximálního výkonu ve }\end{array} \\
\text { vztahu k potenciálu k výkonu } \\
\square \text { Potvrzení v obecné diagnostice a diagnostice } \\
\text { osobnosti: míry typického chování, postojů a } \\
\text { preferencí } \\
\square \quad \text { Jiné: } \\
\quad \text { Není uvedeno }\end{array}$ \\
\hline 1.29 & $\begin{array}{l}\text { Profesionální kvalifikace } \\
\text { vyžadovaná pro používání nástroje }\end{array}$ & $\begin{array}{ll}\square & \text { Žádné } \\
\square & \text { Praktický psycholog s kvalifikací v relevantní } \\
& \text { aplikační oblasti }\end{array}$ \\
\hline
\end{tabular}


1.29 se týká kvalifikací uživatele vyžadovanou dodavatelem. V této části, pokud vydavatel stanovil informace o kvalifikaci uživatele, mělo by to být uvedeno pomocí uvedených kategorií. Kde požadavky na kvalifikaci nejsou jasné, mělo by to být vyjádřeno pomocí “Jiné”, ne "Žádné”. “Žádné” znamená, že existuje explicitní výrok týkající se toho, že není potřeba kvalifikace.
Praktický psycholog

Výzkumný psycholog

Nepsychologický akademický výzkumník

Praktik v relevantních př́buzných profesích (terapie, medicína, poradenství, vzdělání, lidské zdroje atd.)

$\square \quad$ Držitel Certifikátu způsobilosti pro testování v psychologii práce A BPS

Držitel Certifikátu způsobilosti pro testování v oblastni vzdělávacím A BPS

Držitel Certifikátu způsobilosti pro testování v psychologii práce B BPS

Jiné:

\section{Č́st 6:}

\section{Hodnocení testových materiálů}

\section{Vysvětlení hodnocení}

V následujících částech jsou celková posouzení adekvátnosti informací týkajících se validity, reliability a norem zobrazeny automaticky tučně.

Jakýkoli nástroj s jedním nebo více posouzeními 0 nebo 2 týkajícími se atributů považovaných za kritické pro bezpečné používání nástroje, by neměl být považován za nástroj, který splňuje minimální standardy.

\begin{tabular}{|c|c|c|c|}
\hline $\begin{array}{l}\text { Vstup na posuzovacím } \\
\text { formuláři }\end{array}$ & $\begin{array}{l}\text { Posouzení podle } \\
\text { standardů EFPA }\end{array}$ & $\begin{array}{c}\text { Reprezentace recenze } v \\
\mathrm{UK}\end{array}$ & Vysvětlení \\
\hline [n/a] & [n/a ] & [n/a ] & $\begin{array}{l}\text { Tento atribut není u tohoto } \\
\text { nástroje použitelný }\end{array}$ \\
\hline $\mathbf{0}$ & {$[-]$} & [None ] & $\begin{array}{c}\text { Není možné posoudit jako } \\
\text { ne nebo nedostatek } \\
\text { poskytnutých informací }\end{array}$ \\
\hline 1 & {$[-1]$} & {$\left[\begin{array}{ll}* & ]\end{array}\right.$} & Neadekvátní \\
\hline 2 & & {$\left[\begin{array}{ll}* * & ]\end{array}\right.$} & NYNÍ NEPOUŽÍVÁNO \\
\hline 3 & {$\left[\begin{array}{ll}0 & ]\end{array}\right]$} & {$[* * *]$} & Adekvátní nebo přiměřený \\
\hline 4 & [ 1 ] & {$[* * * *]$} & Dobrý \\
\hline \multirow[t]{2}{*}{5} & [ 2 ] & {$[* * * * *]$} & Vynikající \\
\hline & & $\begin{array}{c}\text { [N.r.i.o.r] }{ }^{*} \text { (pouze pro } \\
\text { aktualizace) }\end{array}$ & $\begin{array}{l}\text { Položka nebyla v původní } \\
\text { recenzi posuzována }\end{array}$ \\
\hline
\end{tabular}

V této části má být provedeno více hodnocení různých aspektů nebo atributů dokumentace dodávané s nástrojem (nebo balíkem). Termín „dokumentace“ byl vybrán, aby pokrýval všechny ty materiály dodávané s nástrojem nebo snadno dostupné kvalifikovanému uživateli: např. manual administrátora; technické prŕručky; brožury s normami; dodatky k manuálu; aktualizace od vydavatelů/dodavatelů atd.

Položky mají být posuzovány n/a nebo 0 až 5 (poloviční rating je přijatelný)

Rating

\begin{tabular}{|l|l|c|}
\hline $\begin{array}{l}\text { Kvalita vysvětlení principů, prezentace a kvalita poskytnuté informace: } \\
\text { (Tento celkový rating se získá použitím posouzení založeného na ratinzích daných pro položky 2.1-2.8) }\end{array}$ & $\mathbf{1 , 5}$ \\
\hline 2.1 & $\begin{array}{l}\text { Celkový rating kvality vysvětlení principů: (Tento celkový rating se získá použitím } \\
\text { posouzení založeného na hodnotách ratingů daných pro položky 2.1.1 - 2.1.5) }\end{array}$ & $\mathbf{1}$ \\
\hline
\end{tabular}




\begin{tabular}{|c|c|c|}
\hline 2.1 .1 & i) Teoretické základy konstruktů: & 1 \\
\hline 2.1 .2 & ii) Procedura vývoje testu: & 0 \\
\hline 2.1 .3 & iii) Důkladnost analýz položek a model analýzy položek: & 0 \\
\hline 2.1 .4 & iv) Vysvětlení obsahové validity: & 1 \\
\hline 2.1 .5 & v) Souhrn relevantního výzkumu: & 1 \\
\hline 2.2 & $\begin{array}{l}\text { Adekvátnost dokumentace dostupné uživateli (uživatelské a technické } \\
\text { manuály, dodatky týkající se norem atd.): (Tento celkový rating se získá použitím } \\
\text { posouzení založeného na hodnotách ratingů daných pro položky } 2.2 .1-2.2 .6 \text { ) } \\
\text { Pro část } 2.2 \text { jsou stanoveny následující „měřítka“ pro rating „vynikající“ (5). Pozornost je zde zaměřena } \\
\text { na kvalitu pokrytí poskytnutého v dokumentaci dostupné kvalifikovaným uživatelům. Všimněte si, že část } \\
2.2 \text { se týká úplnosti a jasnosti dokumentace dostupné uživateli (uživatelské a technické manually, doadtky } \\
\text { k normám atd.) v pojmech pokrytí a vysvětlení. V pojmech kvality nástroje, jak ji dosvědčuje dokumentace, } \\
\text { jsou rozpracovány oblasti v této části pod čísly: } 2.1,2.3,2.9,2.10 \text { a } 2.11 \text {. }\end{array}$ & 1,5 \\
\hline 2.2 .1 & $\begin{array}{l}\text { Principy: [viz 2.1] } \\
\text { Dobře argumentovaný a jasně prezentovaný popis toho, co má podle návrhu měřit a proč byl zkonstruován } \\
\text { tak, jak je. }\end{array}$ & 1 \\
\hline 2.2 .2 & $\begin{array}{l}\text { Vývoj: } \\
\text { Úplné detaily týkající se zdrojů položek, pilotáže, analýz položek, srovnávacích studií a změn prováděných v } \\
\text { průběhu vývojových pokusủ. }\end{array}$ & 0 \\
\hline 2.2 .3 & $\begin{array}{l}\text { Standardizace: } \\
\text { Jasné a detailní informace poskytnuté o velikostech a zdrojích standardizačního souboru a standardizační } \\
\text { proceduře. }\end{array}$ & 1,5 \\
\hline 2.2 .4 & $\begin{array}{l}\text { Normy: } \\
\text { Jasné a detailní informace poskytnuté o velikostech a zdrojích normalizačních skupin, podmínkách vyšetření } \\
\text { atd. }\end{array}$ & 1,5 \\
\hline 2.2 .5 & $\begin{array}{l}\text { Reliabilita: } \\
\text { Dobré vysvětlení reliability a široký rozsah měr vnitřní konsistence a retestu spolu s vysvětlením jejich } \\
\text { relevance a zobecnitelnosti nástroje vyšetření. }\end{array}$ & 3 \\
\hline 2.2 .6 & $\begin{array}{l}\text { Validita: } \\
\text { Dobré vysvětlení validity spolu s širokou škálou studií jasně a poctivě popsaných. }\end{array}$ & 1 \\
\hline 2.3 & $\begin{array}{l}\text { Kvalita procedurálních instrukcí poskytnutých uživateli: (Tento celkový rating se } \\
\text { získá s použitím posouzení na základě hodnot ratingů daných pro položky } 2.3 .1-2.3 .7 \text { ) }\end{array}$ & 1,5 \\
\hline 2.3 .1 & $\begin{array}{l}\text { Pro administraci testu: } \\
\text { Poskytnutá jasná a detailní vysvětlení a procedurální průvodce krok za krokem spolu s dobrými radami } \\
\text { týkajícícmi se otázek uchazeču a problémových situací. }\end{array}$ & 3 \\
\hline 2.3 .2 & $\begin{array}{l}\text { Pro skórování testu, normy atd.: } \\
\text { Poskytnuté jasné a detailní informace spolu s popsanými kontrolami pro vyhnutí se možným chybám } \\
\text { skórování. }\end{array}$ & 3 \\
\hline 2.3 .3 & $\begin{array}{l}\text { Pro interpretaci a vytváření zpráv: } \\
\text { Detailní doporučení týkající se interpretace různých skórů, chápání normativních měr a zacházení se vztahy } \\
\text { mezi rưznými škálami, s množstvím ilustrativních př́kladư a př́padových studií. }\end{array}$ & 3 \\
\hline 2.3 .4 & $\begin{array}{l}\text { Pro poskytnutí zpětné vazby a debriefingu respondentům testu a dalším: } \\
\text { Detailní doporučení, jak prezentovat zpětnou vazbu uchazečům. }\end{array}$ & 0 \\
\hline 2.3 .5 & $\begin{array}{l}\text { Pro poskytování dobrých praktických témat týkajících se poctivosti a } \\
\text { zkreslení: } \\
\text { Uvedení detailních informací o studiích sexuálního a etnického zkreslení s relevantními varováními týkajícími } \\
\text { se používání a zobecňování validit. }\end{array}$ & 0 \\
\hline 2.3 .6 & $\begin{array}{l}\text { Omezení používání: } \\
\text { Jasné popisy, kdo by měl a kdo by neměl být vyšetřován spolu s dobře vysvětlenými odůvodněními těchto } \\
\text { omezení (např. typy nezpưsobilostí, požadované úrovně gramotnosti atd.). }\end{array}$ & 0 \\
\hline 2.3 .7 & $\begin{array}{l}\text { Reference a podpůrné materiály: } \\
\text { Detailní odkazy na relevantní podpůrnou akademickou literature a křrižové odkazy na další př́íbuzné } \\
\text { materially týkající se diagnostických nástrojů. }\end{array}$ & 1 \\
\hline \multicolumn{2}{|c|}{$\begin{array}{l}\text { Kvalita materiálů: } \\
\text { (Tento celkový rating se získá použitím posouzení založeného na hodnotách ratingů pro položky } 2.4-2.8 \text { ) }\end{array}$} & 4 \\
\hline 2.4 & $\begin{array}{l}\text { Všeobecná kvalita materiálů testu } \\
\text { (testové brožury, odpověd'ové archy, testové objekty, software atd.): }\end{array}$ & 4 \\
\hline 2.5 & Kvalita lokální adaptace testu (pokud byl test přeložen a adaptován do místního jazyka): & 4 \\
\hline 2.6 & Snadnost, s jakou může respondent testu porozumět úkolu: & 4 \\
\hline
\end{tabular}




\begin{tabular}{|l|l|c|}
\hline 2.7 & $\begin{array}{l}\text { Snadnost, s jakou mohou být respondentem testu tvořeny reakce nebo } \\
\text { odpovědi: }\end{array}$ & 4 \\
\hline 2.8 & Kvalita položek: & 3 \\
\hline
\end{tabular}

\footnotetext{
Recenzentovy komentáře týkající se dokumentace:

(komentáŕe principů, designu, vývoje testu a jeho přijatelnosti)

SVF 78 vznikl zkrácením metody SVF 120 (původní verze z roku 1985, druhá upravená verze z roku 1997 (Weyers, Ising, Reuter a Janke, 2005), všech 13 škál SVF 78 bylo ve stejné podobě převzato z původní delší verze.
}

Při vývoji vycházeli autoři z několika předpokladů: Lidé na stres aktivně reagují snahou o obnovení klidového stavu, tyto způsoby zpracování stresu jsou přitom relativně stabilní v čase a lze je tak pojímat jako osobnostní rys. Lze rozlišit více na sobě relativně nezávislých způsobů zpracování stresu (multidimenzionalita), ty jsou dále relativně nezávislé na druhu zátěžové situace a nejsou rozhodujícím způsobem určovány jinými osobnostními charakteristikami. Způsoby zpracování stresu jsou natolik vědomé, že je možné se na ně přímo dotázat. Autoři přitom sami uvádějí, že některé tyto předpoklady nejsou dosud dostatečně objasněny, výzkumy jsou v některých případech rozporuplné (např. ohledně nezávislosti na situaci). Pokud by některé předpoklady neplatily, byla by ohrožena celková validita metody ( $\mathrm{v}$ př́ípadě závislosti na situaci by napřr. nebylo možné usuzovat na jednání osoby v konkrétních kontextech a metoda by tím pádem ve své obecnosti neměla př́liš smysl).

Způsoby zpracování stresu lze dle autorů také rozdělit podle několika kritérií. Lze rozlišit akční způsoby směřující ke změně nebo odstranění stresoru/reakce na něj a intrapsychické způsoby směřující ke změně vnímání stresoru/reakce. Dále lze strategie rozdělit na zaměřené na stres (reakci při zátěži) a zaměřené na stresor (zátěžovou situaci). Nakonec pak podle účinnosti na pozitivní strategie, které stres spíše snižují a negativní strategie, které stres v důsledku spíše zvyšují.

V manuálu není odkaz na žádnou existující teorii zvládání stresu, pouze v předmluvě pro české vydání Švancara zmiňuje teorii Lazaruse a zároveň dodává, že SVF je konceptualizované v jeho návaznosti. Autoři metody se však k teorii na žádném místě nehlásí, na rozdíl od Lazaruse navíc předpokládají poměrnou nezávislost strategií na situaci. Není zcela jasné, jakým způsobem byl vlastně test vytvořen a z čeho autoři vyvodili používané škály, ani na základě čeho je zařadili mezi pozitivní/negativní strategie. Nic z toho není $\mathrm{v}$ manuálu zmíněno, jediné informace o původu testu se týkají dílčích teoretických předpokladů uvedených výše a jeho odvození z původní verze SVF 120. Informace o konstrukci SVF 120 však nejsou volně dostupné. Balcar, Trnka a Kuška (2011) nicméně uvádí, že nevznikl na základě teorie, ale byl induktivně odvozen z popisu lidí, následné kategorizace a položkové analýzy.

Stejně tak nejsou součástí manuálu informace o vzniku českého překladu ani o psychometrických vlastnostech české verze.

\section{Část 7: \\ Hodnocení norem, reliability a validity}

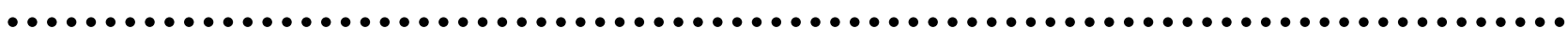




\section{Informace o normách nebo referenční skupině}

\begin{tabular}{|c|c|c|}
\hline 2.9 & Celková adekvátnost: & 1,5 \\
\hline 2.9 .1 & $\begin{array}{cl}\begin{array}{l}\text { Vhodnost pro lokální použití, at' už pro lokální nebo mezinárodní normy: } \\
\text { [n/a] }\end{array} & \text { Nepoužitelné } \\
0 & \text { Žádná informace nepodána. } \\
1 & \text { Není lokálně relevantní (např. nevhodné zahraniční výběry). } \\
3 & \begin{array}{l}\text { Lokální výběr z obecné populace nebo nelokální normy, které lze } \\
\text { použít s varováním. }\end{array} \\
4 & \begin{array}{l}\text { Výběry lokální země nebo relevantní mezinárodní výběry s dobrou } \\
\text { relevancí pro zamýšlenou aplikaci. }\end{array} \\
5 & \begin{array}{l}\text { Výběry lokální země nebo relevantní mezinárodní výběry vybrané z } \\
\text { dobře definovaných výběrů z relevantních aplikačních oblastí. }\end{array}\end{array}$ & 1,5 \\
\hline 2.9 .2 & $\begin{array}{ll}\begin{array}{l}\text { Vhodnost pro zamýšlené aplikace: } \\
\text { [n/a] }\end{array} & \text { Nepoužitelné } \\
0 & \text { Žádná informace nepodána. } \\
1 & \text { Norma nebo normy nejsou adekvátní pro zamýšlené aplikace. } \\
3 & \text { Adekvátní normy pro obecnou populaci a/nebo rozmezí normativních } \\
4 & \text { tabulek. } \\
5 & \begin{array}{l}\text { Dobré rozmezí normativních tabulek. } \\
\text { Vynikajíí rozmezí výběrově relevantních norem vztahujících se k věku } \\
\text { a pohlaví, s informacemi o dalších rozdílech v rámci skupin (např. } \\
\text { směs etnických skupin). }\end{array}\end{array}$ & 1,5 \\
\hline 2.9 .3 & 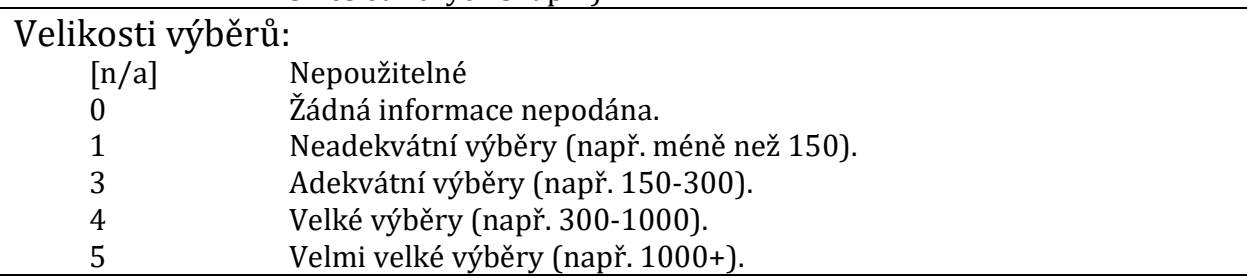 & 1,5 \\
\hline 2.9 .4 & 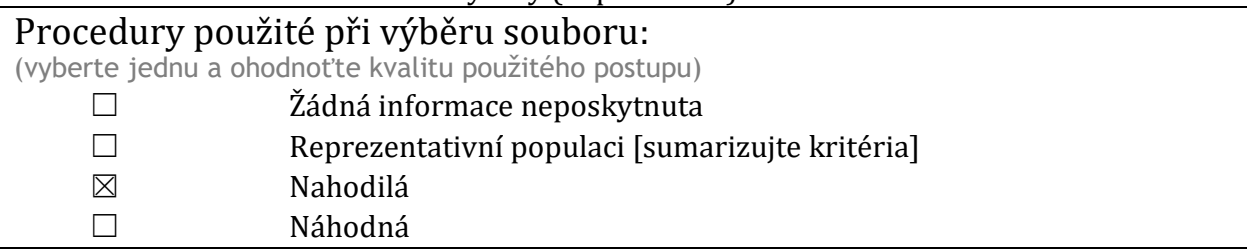 & 1 \\
\hline 2.9 .5 & 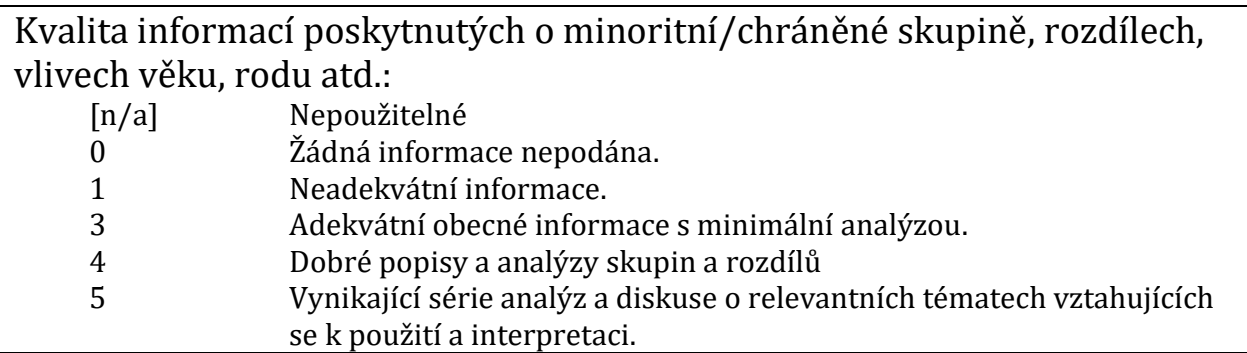 & 3 \\
\hline \multicolumn{3}{|c|}{$\begin{array}{l}\text { 2.9.6 Komentáře recenzentů k normám: Stručná zpráva o normách a jejich historii, včetně informací o doporučeních } \\
\text { učiněných vydavatelem/autorem pro aktualizaci norem obvyklým způsobem. }\end{array}$} \\
\hline \multicolumn{3}{|c|}{$\begin{array}{l}\text { Metoda byla standardizována na německém vzorku } 246 \text { osob, } 122 \text { žen a } 124 \text { mužů ve věku 20-64 let, } \\
\text { většina osob měla středoškolské vzdělání či vzdělání s maturitou, malé množství převážně starších } \\
\text { respondentů pak pouze vzdělání základní. Žádné bližší informace o vzorku však nejsou v manuálu } \\
\text { uvedeny. Z publikované standardizační studie (Weyers, Ising a Janke, 2005) je zřejmé, že respondenti } \\
\text { byli získáni příležitostným výběrem (studenti psychologického kurzu, každý distribuoval dotazník } 5 \\
\text { lidem). Uživatel však nemá žádné údaje o relevantních demografických proměnných, jako je etnicita } \\
\text { či povolání, nemůže si tak být jist reprezentativností vzorku vzhledem k populaci. Autoři se přitom } \\
\text { domnívali, že výsledky budou podobné jako pro vzorek ze standardizace předchozí verze SVF } 120\end{array}$} \\
\hline
\end{tabular}


vzhledem k identickým škálám, je tak možné, že podrobnější informace o standardizaci lze nalézt v manuálu této verze.

Výsledky standardizace jsou uváděny ve formě průměrů a směrodatných odchylek zvlášt' pro pohlaví a pro 3 věkové skupiny: 20-34 let, 35-49 let, 50-64 let. Na základě výsledků analýzy rozptylu byl pozorován vztah pohlaví a věku, muži skórovali výše na škálách Podhodnocení a Odmítání viny (tedy 1. podtyp pozitivních strategií), ženy dosahovaly celkově vyšších hodnot v rámci negativních strategií, konkrétně na škálách Únikové tendence, Perseverace, Rezignace a Sebeobviňování a dále pak na samostatné škále Potřeba sociální opory, velikosti účinku však nejsou uváděny. Co se týče vlivu věku, nejmladší skupina (20-34 let) dosahovala vyšších skórů na škálách Náhradní uspokojení, Potřeba sociální opory a Sebeobviňování, dále pak v rámci celkových negativních strategií a v podtypu pozitivní strategie 2 - Odklon, nejstarší skupina (50-64 let) pak dosahovala vyšších skórů na škále Vyhýbání se, což autoři přičítají možné adaptivní facilitaci s přibývajícím věkem.

České normy testu existují pouze pro počítačově administrovanou metodu, pro metodu tužka papír jsou k dispozici pouze normy zahraniční.

\section{Validita}

\begin{tabular}{|c|c|c|}
\hline 2.10 & $\begin{array}{l}\text { Celková adekvátnost: (Tento celkový rating se získá na základě posouzení hodnot ratingů } \\
\text { daných v položkách } 2.10 .1-2.10 .2 .4 \text {. Neprůměrujte pouze čísla, abyste získali celkový rating. } \\
\text { Obvykle bude roven bud' konstruktové validitě nebo validitě vztahující se ke kritériu, podle } \\
\text { toho, která z nich je vyšší.) }\end{array}$ & 1 \\
\hline 2.10 .1 & $\begin{array}{l}\text { Konstruktová validita - celková adekvátnost } \\
\text { (Tento celkový rating se získá na základě posouzení hodnot ratingů daných v položkách } \\
2.10 .1 .2-2.10 .1 .6 \text {. Neprüměrujte pouze čísla, abyste tento celkový rating získali.) }\end{array}$ & 1,5 \\
\hline 2.10 .1 .1 & $\begin{array}{cl}\text { Použité plány: (zatrhněte tolik, kolikje jich použitelných) } \\
\square \quad \text { Žádná informace nepodána } \\
\square \quad \text { Korelace s dalšími nástroji a výkonovými kritérii } \\
\square \quad \text { Vnitroškálový (korelace položky se zbytkem) } \\
\square \quad \text { Rozdíly mezi skupinami } \\
\square \quad \text { Matice mnoha rysů a mnoha metod (MTMM) } \\
\square \quad \text { Explorační faktorová analýza } \\
\square \quad \text { Konfirmační faktorová analýza } \\
\square \quad \text { Experimentální plány } \\
\square \quad \text { Jiné: }\end{array}$ & \\
\hline 2.10 .1 .2 & $\begin{array}{cl}\text { Velikosti výběrů: } \\
0 & \text { Žádná informace neposkytnuta. } \\
1 & \text { Jedna neadekvátní studie (např. velikost výběru menší než 100). } \\
3 & \text { Jedna adekvátní studie (např. velikost výběru 100-200). } \\
4 & \text { Více než jedna adekvátní nebo velká studie. } \\
5 & \text { Dobrá série adekvátních až rozsáhlých studií. }\end{array}$ & 4 \\
\hline 2.10 .1 .3 & $\begin{aligned} & \text { Procedura výběru souboru: (vyberte jednu) } \\
& \quad \square \quad \text { Žadná informace neposkytnuta } \\
& \square \quad \text { Reprezentativní vǔči populaci [sumarizujte kritéria] } \\
& \square \text { Nahodilá } \\
& \square \text { Náhodná }\end{aligned}$ & \\
\hline 2.10 .1 .4 & $\begin{array}{cl}\text { Medián a rozsah korelací mezi testem a dalšími podobnými testy: } \\
0 & \text { Žádná informace neposkytnuta. } \\
1 & \text { Neadekvátní }(\mathrm{r}<0.55) . \\
3 & \text { Adekvátní }(0.55<\mathrm{r}<0.65) . \\
4 & \text { Dobrý }(0.65<\mathrm{r}<0.75) . \\
5 & \text { Vynikající }(\mathrm{r}>0.75)\end{array}$ & 0 \\
\hline
\end{tabular}




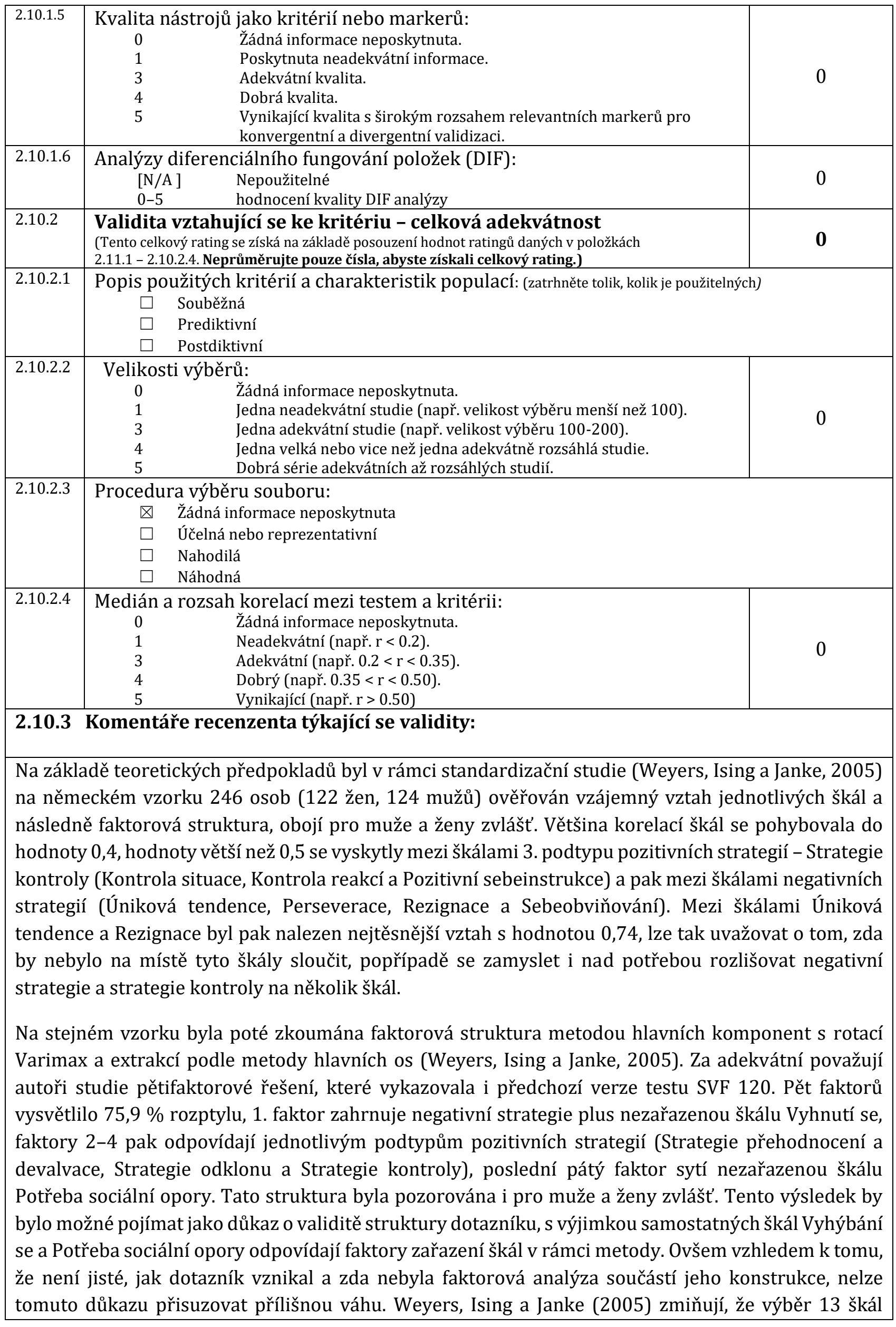


z původní verze byl proveden mimo jiné na základě faktorové struktury. Autoři navíc nezdůvodňují využití modelu s nekorelovanými faktory, vzhledem k vzájemné korelaci jednotlivých škál dotazníku by bylo spíše nasnadě předpokládat mezi faktory vztah. Faktorové řešení není autory dále komentováno, vyjma odkazu na shodnou strukturu starší verze dotazníku. Autoři se nepokoušejí vysvětlit sycení škály Vyhýbání se faktorem negativních strategií, ačkoliv se ukázala mít vyšší náboj než 2 škály „,̌istě“ negativních strategií a ačkoliv takový výsledek příliš neodpovídá jejich pojímání škály jako dvojznačné (žádný faktor pozitivních strategií škálu výrazněji nesytil). Autoři také nevysvětlují význam 5. faktoru, který sytí pouze škálu Potřeba sociální opory, která jinak nebyla sycena ani negativním, ani pozitivními faktory. Význam škály v rámci dotazníku a vliv této strategie na zvládání stresu je tak poněkud záhadou.

Faktorová struktura byla zkoumána i na českém vzorku s českou adaptací dotazníku. Balcar, Trnka a Kuška (2011) provedli explorační faktorovou analýzu s rotací Oblimin na vzorku 187 vysokoškolských studentů (85 mužů, 102 žen) ve věku 19-34 let, přičemž srovnávali možnou tří, čtyř a pětifaktorovou strukturu. Za nejadekvátnější považovali čtyřfaktorovou strukturu podle inspekce vlastních hodnot a sutinového diagramu, $v$ potaz byly přitom brány jen náboje větší než 0,4 . První faktor byl nazván Zhroucení psychických obran, který pozitivně sytil škály negativních strategií a nezařazenou škálu Potřeba sociální opory, a negativně první pozitivní podtyp Strategie přehodnocení a devalvace. Druhý faktor byl nazván Aktivní konfrontace problému a sytil pozitivně podtyp Strategie kontroly a škálu Vyhýbání se. Třetí faktor - Aktivní vyhýbání se situaci sytil pozitivně škály Odklon, Úniková tendence, Náhradní uspokojení a Vyhýbání se. Faktor 4 je pak nazván Psychologická kompenzace a sytí negativně škály Náhradní uspokojení a Potřeba sociální opory a pozitivně škálu Podhodnocení. Odlišná kombinace škál v rámci faktorů koresponduje s nejasným teoretickým zázemím dotazníku, především s tím, že není vysvětlen vztah jednotlivých škál vůči sobě.

Důkazy o konstruktové ani kriteriální validitě nejsou př́liš dostupné. Weyers, Ising a Janke (2005) sice uvádějí, že původní dotazník SVF 120 vykazoval konzistentně konstruktovou validitu v podobě faktorové struktury, konvergentní a diskriminantní validity a externí validitu vyvozenou ze vztahů s jinými škálami měřícími strategie zvládání stresu, k původním článkům, na které odkazují, se mi však nepodařilo dostat.

Kravcová (2015) zkoumala na vzorku 130 českých seniorů souvislost testu s extraverzí a neuroticismem ze zkrácené verze NEO-PI - NEO-FFI. Extraverze se zde ukázala mít slabý pozitivní vztah se všemi podtypy pozitivních strategií ( $\mathrm{r}=0,19-0,20, \mathrm{p}<0,05)$, první dva pozitivní podtypy (Strategie podhodnocení a odmítání viny a Strategie odklonu) se také ukázaly mít slabý negativní vztah s neuroticismem $(\mathrm{r}=-0,19$ a $-0,17, \mathrm{p}<0,05)$. Tento výsledek lze pojímat jako podpoření předpokladu o relativní nezávislosti strategií s osobnostními charakteristikami. Naopak negativní strategie vykazovaly silnější vztah s neuroticismem $(r=0,48, p<0,01)$, což napovídá tomu, že mezi oběma konstrukty bude zásadnější souvislost, než autoři metody předpokládali.

\section{Reliabilita}

\begin{tabular}{|l|l|c|}
\hline 2.11 & $\begin{array}{l}\text { Celková adekvátnost: } \\
\text { (Tento celkový rating se získá na základě posouzení hodnot ratingů daných v položkách 2.11.1-2.10.2.4. } \\
\text { Neprůměrujte pouze čísla, abyste získali celkový rating.) }\end{array}$ & $\mathbf{3}$ \\
\hline
\end{tabular}




\begin{tabular}{|c|c|c|c|}
\hline 2.11.1. & \multicolumn{3}{|c|}{$\begin{aligned} \text { Poskytnutá data týkající se reliability: (vyberte jednu možnost) } \\
\square \quad \text { Uveden pouze jeden koeficient reliability } \\
\square \quad \text { Uveden pouze jeden odhad standardní chyby měření } \\
\square \quad \text { Koeficienty reliability pro několik různých skupin } \\
\square \quad \text { Standardní chyba měření uvedená pro několik rưzných skupin } \\
\end{aligned}$} \\
\hline 2.11 .1 & \multicolumn{3}{|c|}{ Vnitřní konzistence: } \\
\hline 2.11 .1 .1 & \multicolumn{2}{|c|}{$\begin{array}{cl}\text { Velikost výběru: } \\
0 & \text { Neposkytnuta žádná informace. } \\
1 & \text { Jedna neadekvátní studie (napřr. rozsah výběru menší než 100). } \\
3 & \text { Jedna adekvátní studie (napr.r rozsah výběru 100-200). } \\
4 & \text { Jedna rozsáhlá nebo vice než jedna adekvátně rozsáhlá studie. } \\
5 & \text { Dobrá série adekvátních až rozsáhlých studií. } \\
{[\mathrm{N} / \mathrm{A}]} & \text { Nepoužitelné. } \\
\end{array}$} & 4 \\
\hline 2.11 .1 .2 & $\begin{array}{l}\text { Medián koeficiel } \\
\quad 0 \\
1 \\
3 \\
4 \\
5 \\
{[\mathrm{~N} / \mathrm{A}]}\end{array}$ & 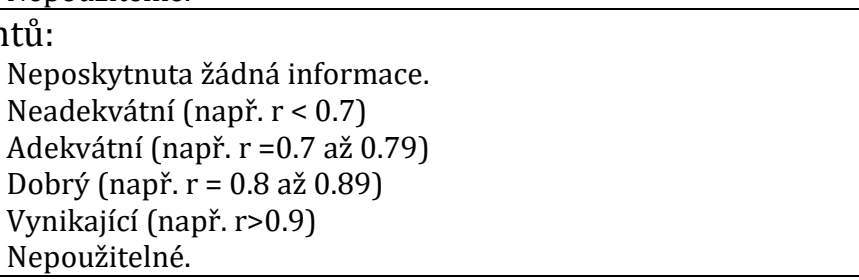 & 3 \\
\hline 2.11 .2 & \multicolumn{3}{|c|}{ *Testová-retestová stabilita: } \\
\hline 2.11 .2 .1 & $\begin{array}{l}\text { Rozsah výběru: } \\
0 \\
1 \\
3 \\
4 \\
5 \\
\end{array}$ & $\begin{array}{l}\text { Neposkytnuta žádná informace. } \\
\text { Jedna neadekvátní studie (napřr. rozsah výběru menší než 100). } \\
\text { Jedna adekvátní studie (napřr. rozsah výběru 100-200). } \\
\text { Jedna rozsáhlá nebo vice než jedna adekvátně rozsáhlá studie. } \\
\text { Dobrá série adekvátních až rozsáhlých studií. }\end{array}$ & 3 \\
\hline 2.11 .2 .2 & $\begin{array}{l}\text { Medián koeficier } \\
0 \\
1 \\
3 \\
4 \\
5\end{array}$ & $\begin{array}{l}\text { Nepo̊: } \\
\text { Neposkytnuta žádná informace. } \\
\text { Neadekvátní (nap̌r. } r<0.6 \text { ) } \\
\text { Adekvátní (napřr. } r=0.6 \text { až } 0.69 \text { ) } \\
\text { Dobrý (napřr. } r=0.7 \text { až } 0.79 \text { ) } \\
\text { Vynikající (např. } r>0.8 \text { ) }\end{array}$ & 4 \\
\hline 2.11 .3 & \multicolumn{3}{|c|}{ Reliabilita jako ekvivalence: } \\
\hline 2.11 .3 .1 & $\begin{array}{l}\text { Rozsah výběru: } \\
0 \\
1 \\
3 \\
4 \\
5 \\
{[\mathrm{~N} / \mathrm{A}]} \\
\end{array}$ & $\begin{array}{l}\text { Neposkytnuta žádná informace. } \\
\text { Jedna neadekvátní studie (napřr. rozsah výběru menší než 100). } \\
\text { Jedna adekvátní studie (napřr. rozsah výběru 100-200). } \\
\text { Jedna rozsáhlá nebo vice než jedna adekvátně rozsáhlá studie. } \\
\text { Dobrá série adekvátních až rozsáhlých studií. } \\
\text { Nepoužitelné. }\end{array}$ & [n/a] \\
\hline 2.11.3.2 & $\begin{array}{l}\text { Medián koeficier } \\
\quad 0 \\
1 \\
3 \\
4 \\
5 \\
{[\mathrm{~N} / \mathrm{A}]}\end{array}$ & $\begin{array}{l}\text { tů: } \\
\text { Neposkytnuta žádná informace. } \\
\text { Neadekvátní (např. } r<0.6) \\
\text { Adekvátní (např. } r=0.6 \text { až } 0.69 \text { ) } \\
\text { Dobrý (napřr. } r=0.7 \text { až } 0.79 \text { ) } \\
\text { Vynikající (napřr. } r>0.8 \text { ) } \\
\text { Nepoužitelné }\end{array}$ & {$[\mathrm{n} / \mathrm{a}]$} \\
\hline \multicolumn{4}{|c|}{$\begin{array}{l}\text { 2.11.4 Komentáře recenzentů k reliabilitě: } \\
\text { - Komentujte intervaly spolehlivosti pro koeficienty reliability } \\
\text { - Uvedte Spearmanovy-Brownovy ekvivalenty }\end{array}$} \\
\hline \multicolumn{4}{|c|}{$\begin{array}{l}\text { V rámci standardizace metody (Weyers, Ising a Janke, 2005) byly na vzorku } 246 \text { osob, } 122 \text { žen a } 124 \\
\text { mužů ve věku } 20-64 \text { let zjištěny hodnoty Cronbachovo } \alpha \text { pro jednotlivé škály } 0,77-0,94 \text { a pro celkové } \\
\text { pozitivní a negativní strategie a podtypy pozitivních strategií } 0,86-94 \text {. Hodnoty split-half reliability } \\
\text { se pak pro škály pohybovaly mezi } 0,74-0,95 \text {, pro pozitivní a negativní strategie } 0,85-0,96 \text {. Odhady } \\
\text { reliability zde byly počítány pro muže a ženy zvlášt', vycházely ale velmi podobně, pouze u škál } \\
\text { Náhradní uspokojení a Rezignace se objevily malé rozdíly. Reliabilita nicméně nebyla zkoumána } \\
\text { zvlášt' pro jednotlivá věková období, což může souviset i s poměrně malou velikostí vzorku. V rámci } \\
\text { předchozí verze dotazníku SVF } 120 \text { vycházela na vzorku } 140 \text { osob ( } 69 \text { mužů, } 71 \text { žen) Cronbachovo } \alpha \\
\text { a split-half reliabilita pro všechny škály a strategie vyšší než } 0,7 \text {, pro většinu pak více jak } 0,8 \text { a split- }\end{array}$} \\
\hline
\end{tabular}


half reliabilita strategií vyšší než 0,9 . Test-retest reliabilita po jednom měsíci pak vycházela pro všechny škály větší než 0,7 (Ising, Weyers, Reuter a Janke, 2006).

S použitím české verze byla na vzorku 130 seniorů ve věku 60-75 let (55 mužů, 75 žen) zjištěna poněkud nižší vnitřní konzistence celkových strategií a pozitivních podtypů v rozmezí $0,65-0,84$, hodnoty pro jednotlivé škály nejsou bohužel uváděny (Kravcová, 2015).

Č́st 9:

\section{Závěrečné hodnocení:}

\subsection{Hodnotící zpráva testu:}

Tato část by měla obsahovat stručné, jasně obhájené posouzení nástroje/produktu. Mělo by popisovat jeho pro a proti a poskytnout určitá obecná doporučení týkající se toho, jak a kdy by se měl používat - spolu s varováními (kde jsou potřebná) týkajícími se případů, kde by se používat neměl.

Ačkoliv je dotazník strategií zvládání stresu označován za nejčastěji používanou metodu zvládání stresu v Německu (Mayers, Ising a Janke, 2005), nepodařilo se mi najít větší množství studií v anglickém jazyce, které by s dotazníkem pracovaly. Výzkumy zvládání stresu často využívaly některou z jiných existujících metod a v případě, že používaly některou z verzí SVF, se většinou nevěnovaly jejím psychometrickým vlastnostem. Několik studií, na které autoři odkazovali v manuálu a které mi přišly dosti zásadní pro porozumění metodě, obzvláště její konstrukci a teoretickým východiskům, jsou k dostání pouze zpoplatněné.

Manuál je celkově velmi stručný a neobsahuje mnohé relevantní informace. Autoři přitom často odkazují na manuál předchozí verze testu - SVF 120. Domnívám se, že to není příliš št’astné řešení, pro lepší porozumění teorii i způsobu vývoje by uživatel potřeboval manuál starší verze a nelze očekávat, že jej vlastní či že je celkově s předchozí verzí metody blíže seznámen. Předpoklad znalosti předchozí verze mi přijde ještě méně oprávněný vzhledem $\mathrm{k}$ tomu, že se nejedná o univerzálně známou a široce využívanou metodu (minimálně ne mimo německy mluvící země), u které by mohl být podobný př́ístup více pochopitelný. Dalo by se tak říci, že jako jeden z nejzásadnějších nedostatků metody vnímám nedostupnost informací.

Na metodě lze ocenit dobrou reliabilitu škál i strategií odhadovanou různými způsoby - Cronbachovo $\alpha$, split-half reliabilita a test-retest reliabilita. Naopak vytknout je třeba nedostatečné teoretické zázemí (zmiňovány jsou pouze základní předpoklady pojetí stresu a zběžné nastínění významu škál), absenci popisu vývoje škály, nedostatečné informace o spíše skromnějším standardizačním vzorku a otázka jeho reprezentativnosti, nejasný vztah jednotlivých škál dotazníku související s jeho faktorovou strukturou a také neprokázanou validitu nástroje. V kontextu české adaptace jsou pak dosti problematické chybějící informace o překladu a neexistence tuzemských norem.

Co se týče samotného obsahu dotazníku, některé formulace $\mathrm{v}$ rámci jedné škály mohou dle mého názoru zachycovat poněkud odlišné věci (přání/plánování vs. realita), což může znesnadnit interpretaci. Například v rámci škály Kontrola situace, která je řazena k pozitivním strategiím, se vyskytují položky tázající se jednak na plánování kontroly situace a jednak na reálnou aktivní snahu situaci kontrolovat. Domnívám se, že pouhé plánování nemusí vypovídat o reálném využívání této strategie a nemusí také přispívat k efektivnímu zvládání stresu. Naopak by mohlo nabývat podoby ulpívavého myšlení (škála Perseverace) a tudíž být spíše kontraproduktivní strategií. To může umocňovat celkovou nejasnost ohledně jednotlivých škál a jejich vzájemných vztahů, stejně jako jejich zařazení do pozitivních nebo negativních strategií. 


\begin{abstract}
3.1 Závěry:
Výtek je poměrně mnoho a nejsou zanedbatelné, domnívám se proto, že v současné podobě není metoda vhodná pro autory zamýšlené účely - pro srovnávání skupin v oblasti psychologie zdraví, psychologie nemoci a pracovní psychologie, individuální diagnostiku sami autoři nedoporučují kvůli nedostatku validizačních studií. Obzvláště užití v pracovní psychologii mi přijde problematické, vzhledem k nejasnému teoretickému základu a absenci validizačních studií by byla práce s metodou v tomto kontextu neoprávněná a neetická. Sami autoři navíc upozorňují na nebezpečí záměrného zkreslování výsledků a metoda neobsahuje žádný lži-skór, její využití by tak nemuselo mít ani př́lišnou výpovědní hodnotu. $\mathrm{V}$ českém prostředí jsou navíc problémem zahraniční normy. Metodu tak doporučuji raději pouze pro výzkum, minimálně do doby, než bude stát na pevnějších teoretických základech a bude prokázána její validita. Zajímavou cestou v tomto směru může být přístup Balcara, Trnky a Kušky (2011), kteří se nalezenou faktorovou strukturu české verze dotazníku pokusili poměrně úspěšně interpretovat pomocí Lazarusova transakčního modelu stresu.
\end{abstract}

\subsection{Doporučení (vyberte jedno)}

Všechny následující charakteristiky uvedené níže by měly mít ratingy [n/a], [2], [4], [5], pokud by měl být nástroj „doporučen“ pro obecné použití (hodnocení 5 nebo 6):

[2.9] Normy a referenční skupiny

[2.10.1] Konstruktová validita

[2.10.2] Kriteriální validita

[2.11] Reliabilita - celková

[2.12] Počítačově generované

zprávy

Pokud má kterýkoli z výše uvedených ratingů hodnotu [] nebo [1], nástroj by měl být klasifikován pod doporučením 1, 2, 3 nebo 4, nebo klasifikován pod doporučením 7 "jiné" s adekvátním vysvětlením.
1 Pouze výzkumný nástroj. Ne pro užití v praxi.

2 Vhodný pouze pro užití expertním uživatelem za pečlivě kontrolovaných podmínek nebo ve velmi omezených aplikačních oblastech

3 Vhodný pro použití pod supervizí $\mathrm{v}$ aplikační(ch) oblasti(ech) definovaných distributorem, libovolnými uživateli s obecnými kompetencemi pro používání a administraci testů

\ 4 Vyžaduje další vývoj. Vhodný pouze pro použití ve výzkumu.

5 Vhodný pro používání $\mathrm{v}$ aplikační(ch) oblasti(ech) definovaných distributorem, uživateli testů, kteří splňují speciální kvalifikační požadavky distributora

6 Vhodný pro sebevyšetření bez supervise $\mathrm{v}$ aplikační(ch) oblasti(ech) definovaných distributorem

7 Jiné:

\title{
5 Odkazy k poznámkám a bibliografie
}

Balcar, K., Trnka, R., \& Kuška, M. (2011). How Many Ways to Deal With Stress? Stress coping factors in the SVF 78. Activitas Nervosa Superior, 53(1-2), 27-34.

Ising, M., Weyers, P., Reuter, M., \& Janke, W. (2006). Comparing two approaches for the assessment of coping: Part II. Differences in stability in time. Journal of Individual Differences, 27(1), 15-19.

Janke, W. \& Erdmann, G. (2003). Strategie zvládání stresu. Praha: Testcentrum.

Kravcová, M. Selected personality characteristics and coping strategies as predictors of life satisfaction of the eldres. E-psychologie [online], 9(4), 12-23.

Weyers, P., Ising, M., \& Janke, W. (2005). Effects of imagined stress intensity on responses in a stress coping inventory. Anxiety, Stress \& Coping, 18(2), 117-130.

Weyers, P., Ising, M., Reuter, M., \& Janke, W. (2005). Comparing two approaches for the assessment of coping: Part I. Psychometric properties and intercorrelations. Journal of Individual Differences, 26(4), 207-212. 


\section{Měřené konstrukty:}

Dotazník se skládá z 13 škál: Podhodnocení, Odmítání viny, Odklon, Náhradní uspokojení, Kontrola situace, Kontrola reakcí, Pozitivní sebeinstrukce, Potřeba sociální opory, Vyhýbání se, Úniková tendence, Perseverace, Rezignace, Sebeobviňování.

Škály lze dále rozřadit na pozitivní (škály Podhodnocení, Odmítání viny, Odklon, Náhradní uspokojení, Kontrola situace, Kontrola reakce, Pozitivní sebedestrukce) a negativní strategie (škály Úniková tendence, Perseverace, Rezignace, Sebeobviňování), škály Potřeba sociální opory a Vyhýbání se nejsou řazeny ani do jednoho typu strategií a stojí samostatně. 